\title{
New and interesting records of Diptera on glacial sand deposits in Silesia (NE Czech Republic). Part 2 - Brachycera except for Schizophora
}

\author{
Jindřich Roháček, Miroslav Barták, Alois Čelechovský, \\ Patrick Grootaert, Liliana Kanavalová, Libor Mazánek \& Marc Pollet
}

\begin{abstract}
New and interesting records of Diptera on glacial sand deposits in Silesia (NE Czech Republic). Part 2 - Brachycera except for Schizophora. - Acta Mus. Siles. Sci. Natur. 70: 1-32, 2021.

Abstract: Records of 19 species of the dipteran families Bombyliidae (1 species), Mythicomyiidae (1 species), Therevidae (2 species), Empididae (3 species), Hybotidae (1 species), Dolichopodidae (8 species) and Syrphidae (3 species) from glacial sand deposits in the Czech Silesia (NE Czech Republic) are presented and their association with sandy habitats discussed. All of them are recorded from the Czech Silesia for the first time, 13 are new additions to the fauna of Moravia of which 9 are also new for the whole of the Czech Republic. Dialineura anilis (Linnaeus, 1761) (Therevidae) and Schistostoma truncatum (Loew, 1864) (Dolichopodidae) are classified as psammobiont, 6 species as psammophilous, viz. Exhyalanthrax afer (Fabricius, 1794) (Bombyliidae), Cliorismia rustica (Panzer, 1804) (Therevidae), Cryptophlebs kerteszi Lichtwardt, 1898, Melanostolus melancholicus (Loew, 1869) (both Dolichopodidae) and Paragus constrictus Šimić, 1986 and Pelecocera tricincta Meigen, 1822 (Syrphidae), and 3 species as probably psammophilous, viz. Medetera annulitarsus von Roser, 1840, M. grunini Negrobov, 1966 and Sciapus basilicus Meuffels \& Grootaert, 1990 (all Dolichopodidae). Medetera grunini is recorded for the first time from Europe and represents a new westernmost limit of its distribution range in the Palaearctic. New southernmost records of Rhamphomyia murina Collin, 1926 (Empididae) and Drapetis monsmargila Grootaert, Beuk \& Shamshev, 2020 (Hybotidae) are also given.
\end{abstract}

Key words: Diptera, Bombyliidae, Mythicomyiidae, Therevidae, Empididae, Hybotidae, Dolichopodidae, Syrphidae, new records, psammophily, glacial sand deposits, Czech Republic (Moravia/Silesia)

\section{Introduction}

This contribution is a further continuation of studies devoted to the fauna of Diptera associated with glacial sand habitats in the Czech Silesia (NE part of the Czech Republic), cf. Roháček et al. (2020). Deposits of glacial sediments in this region were formed during several Pleistocene glaciations, particularly during the most extensive Saalian glaciation about 160000 ya, see Růžička (2004), Růžičková et al. (2009) and Nývlt (2011). In the contemporary Silesian landscape these sand deposits are mostly covered by a soil mantle of a more recent (Holocene) age and, consequently, the habitats with exposed sands are infrequent, space-limited and mainly occur in sand-pits. On the exposed glacial sands a distinctive ecosystem is formed that has a distinctly insular character as it differs markedly from the surrounding (mostly agricultural or production forestry) ecosystems (Roháček 2020).

The fauna of Diptera inhabiting sandy ecosystems is also specific but has mainly been studied in coastal sand dunes (Karl 1930, Krogerus 1932, Ardö 1957, Howe 2010, Nielsen et al. 2016, 2019) while its knowledge on inland sandy habitats remains poor. Therefore, a project aimed at the investigation of the Diptera biodiversity in glacial sand habitats in Silesia has been designed to better understand their dipteran communities and to determine the degree of association of particular species to these sandy habitats. Some information on a few species of Diptera occurring in sand-pits in Silesia can be found in Roháček \& Ševčík (2013) but much more results have been obtained during research within the above project, some of which have 
already been published (Roháček 2015a, 2016a, 2020; Roháček et al. 2020). The field work was conducted in 9 localities in four parts of the Czech Silesia, viz. in the Jesenicko, Osoblažsko, Hlučínsko and Karvinsko regions (see map on Fig. 3), in 2013-2020. However, also material obtained previously $(1995-1997,2004)$ in a few sand-pits and allied sandy sites in the Hlučínsko and Osoblažsko regions (deposited in SMOC) has been used for this paper.

A number of species of interest, including faunistic novelties, psammobiont or psammophilous, xerophilous and/or thermophilous species have been recorded during the above research. Some of these species have been dealt with by Roháček (2015a,b, 2016a, 2020) and Roháček et al. (2020) but records of others remain unpublished, including those obtained in 1995-1997 and 2004. Similarly, as in the previous study (Roháček et al. 2020), we here present a series of mainly faunistically important records, now devoted to lower Brachycera of the families Bombyliidae, Mythicomyiidae, Therevidae, Empididae, Hybotidae, Dolichopodidae and Syrphidae. Some of these species represent new additions to the fauna of the Czech Republic, others to Moravia and the remaining to the Czech Silesia. Of each species, we have gathered information on its biology and distribution from both the literature and personal experience and field work to classify its affinity to sandy habitats.

\section{Material and methods}

The material examined is deposited in the collection of the Silesian Museum, Opava, Czech Republic (SMOC) except for a few duplicates retained by the taxonomic experts involved in this study. The collected specimens were air-dried and mounted on pinned triangular cards in the course of the study but some of them were retained alive in plastic tubes for a while to be photographed by means of a digital camera (Canon EOS 60D) with a macro lens (Canon MP-E $65 \mathrm{~mm} \mathrm{1-5 \times )} \mathrm{and} \mathrm{ring} \mathrm{macro} \mathrm{flash} \mathrm{(Canon} \mathrm{MR-14EX).} \mathrm{After} \mathrm{photography} \mathrm{these}$ specimens were killed and mounted for subsequent identification in the same way as the other specimens. Where necessary, male genitalia or female postabdomina were examined after detachment and dissection of the whole abdomen. After examination, all parts were transferred to polymer microvials which were pinned below the respective specimens. Habitat photographs were taken in the field by digital cameras Canon EOS 60D and/or Sony NEX-7.

The historic region of Silesia (the Czech part of Silesia), as delimited in Př́roda Slezska (see Fig. 3 and/or Roháček et al. 2013, map on pp. 10-12), is treated within (the historical country) Moravia in all checklists of Diptera of the Czech Republic and Slovakia, including the most recent one (Jedlička et al. 2009). To display its location, this region is depicted on a map of the Czech and Slovak Republics (see Fig. 2) used in Jedlička et al. (2009). Because the Czech Silesia has been considered a part of Moravia in these checklists the area under study is listed as "N Moravia" in the material examined below to be in conformity also with previous faunistic studies.

Localities under study. Field work was performed in 2013-2020 in four regions of the Czech Silesia. Sandpits were paired by proximity with one being actively utilized for sand extraction and the other left abandoned. A large abandoned sand-pit in Godów in S. Poland was also included in the project to complement the active sandpit in Dolní Lutyně. The only sites with natural occurrence of glacial sand in the Czech Silesia (Bělá nr. Chuchelná, "Buben" sand-hill and Bělá nr. Chuchelná, natural outcrop of sand at holt) have also been included in the study (see below). For landscape photographs of all localities see Roháček (2020: figs 6-18). Localities are listed below according to these regions and arranged from west to east (see Fig. 3):

Jesenicko region:

(1) Supíkovice $1.1 \mathrm{~km} \mathrm{NE}, 50^{\circ} 18^{\prime} 22^{\prime \prime} \mathrm{N}, 17^{\circ} 15^{\prime} 43^{\prime \prime} \mathrm{E}, 380 \mathrm{~m}$, large abandoned sand-pit;

(2) Kolnovice, active sand-pit, two plots - Kolnovice $1 \mathrm{~km} \mathrm{SW}, 50^{\circ} 18^{\prime} 55^{\prime \prime} \mathrm{N}, 1^{\circ} 18^{\prime} 45^{\prime \prime} \mathrm{E}, 385 \mathrm{~m}$ (C part) and Kolnovice $1.2 \mathrm{~km}$ WSW, 50¹8'59"N, 17¹8'35"E, $390 \mathrm{~m}$ (W part).

Osoblažsko region:

(3) Bohušov $0.7 \mathrm{~km} \mathrm{~S}, 50^{\circ} 14^{\prime} 14^{\prime \prime} \mathrm{N}, 17^{\circ} 42^{\prime} 58^{\prime \prime} \mathrm{E}, 250 \mathrm{~m}$, abandoned sand-pit;

(4) Bartultovice $0.5 \mathrm{~km} \mathrm{SW}, 50^{\circ} 16^{\prime} 13^{\prime \prime} \mathrm{N}, 17^{\circ} 35^{\prime} 00^{\prime \prime} \mathrm{E}, 315 \mathrm{~m}$, small abandoned sand-pit.

Hlučínsko region:

(5) Oldřišov 0.7 km N, sand-pit, 4959'51"N, 1757'48"E, $280 \mathrm{~m}$, abandoned sand-pit;

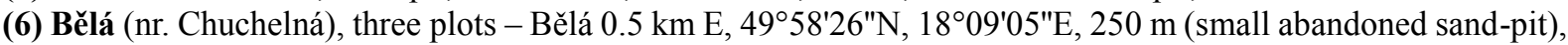
Bělá 0.4 km NE, "Buben“" sand-hill, 49॰58'29"N, 1809'01"E, 260 m (natural outcrop of sand) and Bělá 0.6 km N, $49^{\circ} 58^{\prime} 39^{\prime \prime} \mathrm{N}, 18^{\circ} 08^{\prime} 49^{\prime \prime} \mathrm{E}, 265 \mathrm{~m}$ (holt on natural outcrop of sand); 


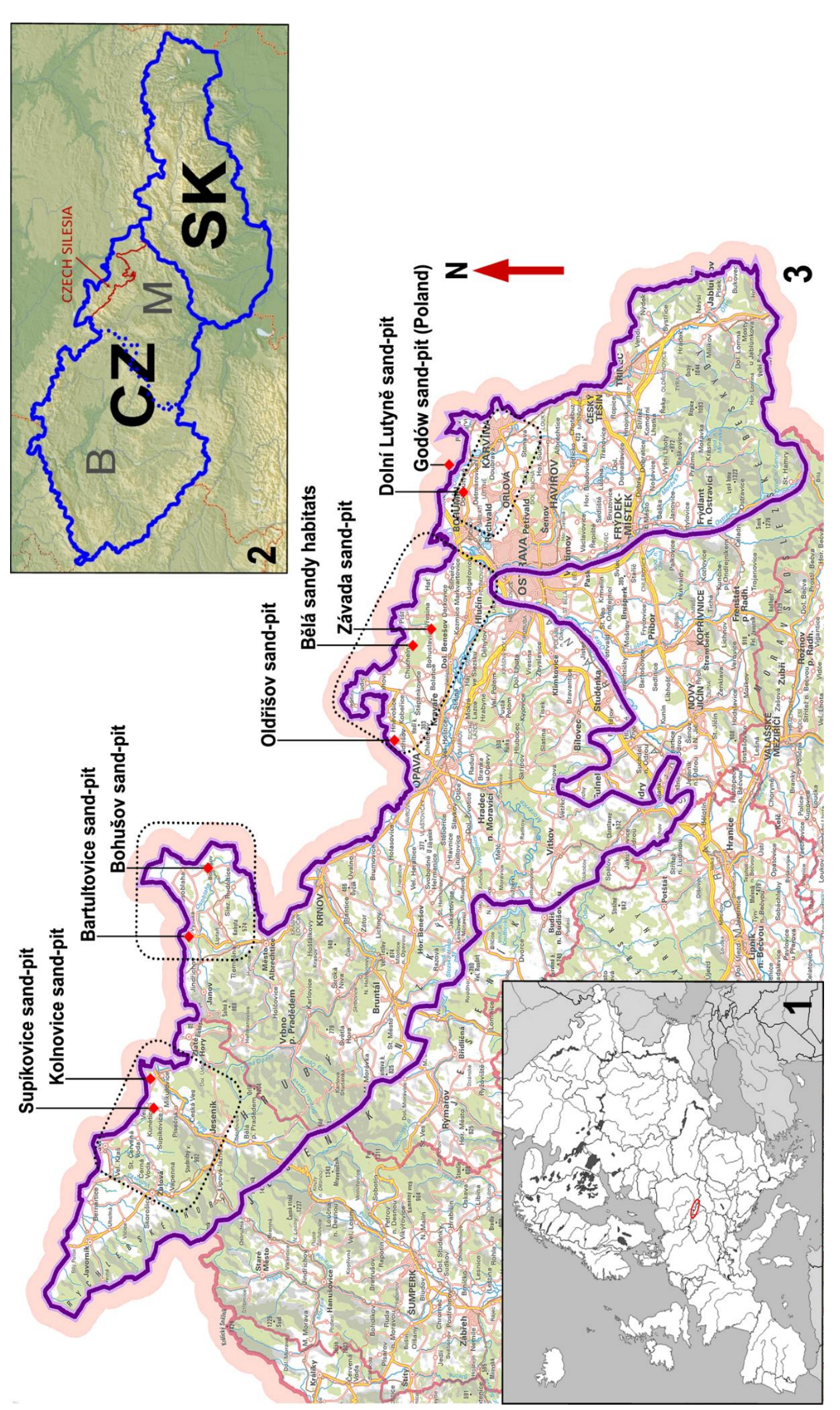

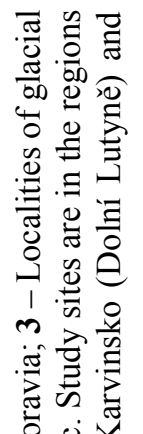

它.

言焉

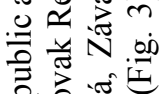

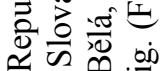

舟

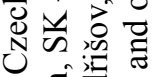

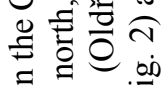

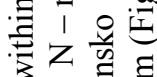

. .

额言

की

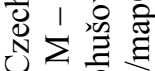

ㅇํㅇ

फ

.을 总

敢 岕

। थ

$\therefore N$ 웅

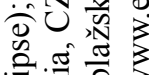

힐

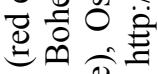

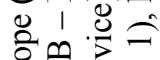

它

$\Xi$ 至

.

的焉

गٓ

․․

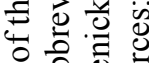

ธิ से ठ্

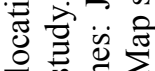

1 离司

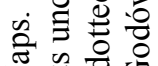

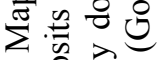

$\ddot{i}$ 合

1 可 
(7) Závada, active sand-pit, three plots - Závada $1.8 \mathrm{~km} \mathrm{SE}, 49^{\circ} 56^{\prime} 19^{\prime \prime} \mathrm{N}, 18^{\circ} 10^{\prime} 28^{\prime \prime} \mathrm{E}, 260 \mathrm{~m}$ (SE part, partly recultivated), Závada $2 \mathrm{~km} \mathrm{~S}, 49^{\circ} 56^{\prime} 09^{\prime \prime} \mathrm{N}, 18^{\circ} 10^{\prime} 04^{\prime \prime E}, 270 \mathrm{~m}$ (SW part, not excavated but regularly disturbed) and Závada $1.6 \mathrm{~km} \mathrm{~S}, 49^{\circ} 56^{\prime} 25^{\prime \prime} \mathrm{N}, 18^{\circ} 09^{\prime} 56^{\prime \prime} \mathrm{E}, 265 \mathrm{~m}$ (NW part, with active excavation).

Karvinsko region:

(8) Dolní Lutyně 1.2 km N, 4954'34"N, 18²5'33"E, 210 m, active sand-pit with two artificial lakes after excavation.

S. Poland:

(9) Godów $1.3 \mathrm{~km}$ ESE, 495'13"N, 18²9'41"E, $230 \mathrm{~m}$, large abandoned sand-pit (close to Czech-Polish borders).

Collecting methods. The flies were collected by sweeping over sparse low vegetation or bare sand; netting of individually observed specimens, hand or aspirator collecting on flowering plants and decaying substrates on sandy ground was also applied.

Nomenclature. Botanical nomenclature follows that used in the Checklist of vascular plants of the Czech Republic (Danihelka et al. 2012). Nomenclature of flies follows the most recent catalogues, checklists, monographs and/or revisions of the groups recorded here.

Assessment of the affinity of species to sandy habitat. The affinity of a species to sand has been judged by the corresponding taxonomic expert based on his knowledge of the biology, autecology and distribution of the species. Four categories are differentiated according to the degree of association with sandy habitats:

(1) psammobiont - species strictly associated (including reproduction and entire life-cycle) with sandy habitats.

(2) psammophilous - species preferably associated with sandy habitats but also living in related xerothermic habitats like various types of xeric steppe and rocky grassland.

(3) psammoneutral - species with a wide habitat tolerance utilizing various habitats and successfully also living in habitats on sandy soils.

(4) psammoxenous - species coincidentally encountered in sandy habitats only by chance, not developing there.

These categories can be compared with those generally used in North Europe (e.g. Krogerus 1960) as follows: psammobiont $=$ eucoenic $($ euzön $)$, psammophilous $=$ tychocoenic $($ tychozön $)$, psammoneutral $=$ acoenic $($ azön $)$, psammoxenous $=$ xenocoenic $($ xenozön $)$.

Author contributions. J. Roháček conceptualized the study, performed the field work, designed the manuscript, and treated the families Therevidae, Mythicomyiidae and all general parts of this paper; co-authors identified material and prepared sections on the families or groups as follows: M. Barták and L. Kanavalová (Empididae and Schistostoma in Dolichopodidae: Microphorinae), J. Čelechovský (Bombyliidae), P. Grootaert (Hybotidae: Drapetis), M. Pollet (Dolichopodidae) and L. Mazánek (Syrphidae).

\section{Results}

\section{BOMBYLIIDAE}

Exhyalanthrax afer (Fabricius, 1794) - psammophilous

Material examined: CZECH REPUBLIC: N Moravia: Bělá nr. Chuchelná $0.4 \mathrm{~km}$ NE, „Buben“ sand-hill, $49^{\circ} 58^{\prime} 29^{\prime \prime} \mathrm{N}, 18^{\circ} 09^{\prime} 01^{\prime \prime} \mathrm{E}, 260 \mathrm{~m}$, sweeping over sand \& vegetation on sand, 3.7.2017, 1오. J. Roháček leg. et det., A. Čelechovský rev. (SMOC).

Biology: E. afer is a thermophilous species, uncommon to rare in Central Europe. Its hyperparasitic larvae are reported as parasitoids of pupae of Tachinidae and Ichneumonidae developing in pupae of the pine processionary caterpillar Thaumetopoea pityocampa (Denis \& Schiffermüller, 1775) and some other Lepidoptera and also in cocoons of the pine sawfly, Neodiprion sertifer (Geoffroy in Fourcroy, 1785), see in Merle (1975) and Greathead \& Grandcolas (1995). The species hibernates in the mature larval stage; it pupates in spring (Motyčková 2012). Adults have been observed from VII to IX in the Czech Republic (Bosák 1997) and occur in various xeric habitats including bare sands and, less often, heaths (Čelechovský et al. 2021). In the study area it was only found on a natural outcrop of glacial sand (called Buben) at Bělá village in the Hlučínsko region, where a single specimen was netted from a spot of particularly insolated sandy ground (Fig. 5), i.e. in the same habitat where also Anthrax varius Fabricius, 1794 occurs.

Distribution: Widespread in temperate and southern Europe but absent in Great Britain and northern Europe (Greathead 2013a). In the Palaearctic, it is also known from North Africa, the Middle East and Asia (Evenhuis \& Greathead 1999, 2003). The species is rare in the Czech Republic, with only 3 old records from the Polabí area 
in central Bohemia and 8 records (both old and recent) from southern and central Moravia (Tomaj 1977, Bosák 1997, 1998, Motyčková 2012, Čelechovský et al. 2021), all restricted to the warmest lowland parts of the country. First record from the Czech Silesia and northern Moravia.

Comments: $E$. afer is here considered a psammophilous species due to prevailing occurrence in warm, xeric and sandy habitats.
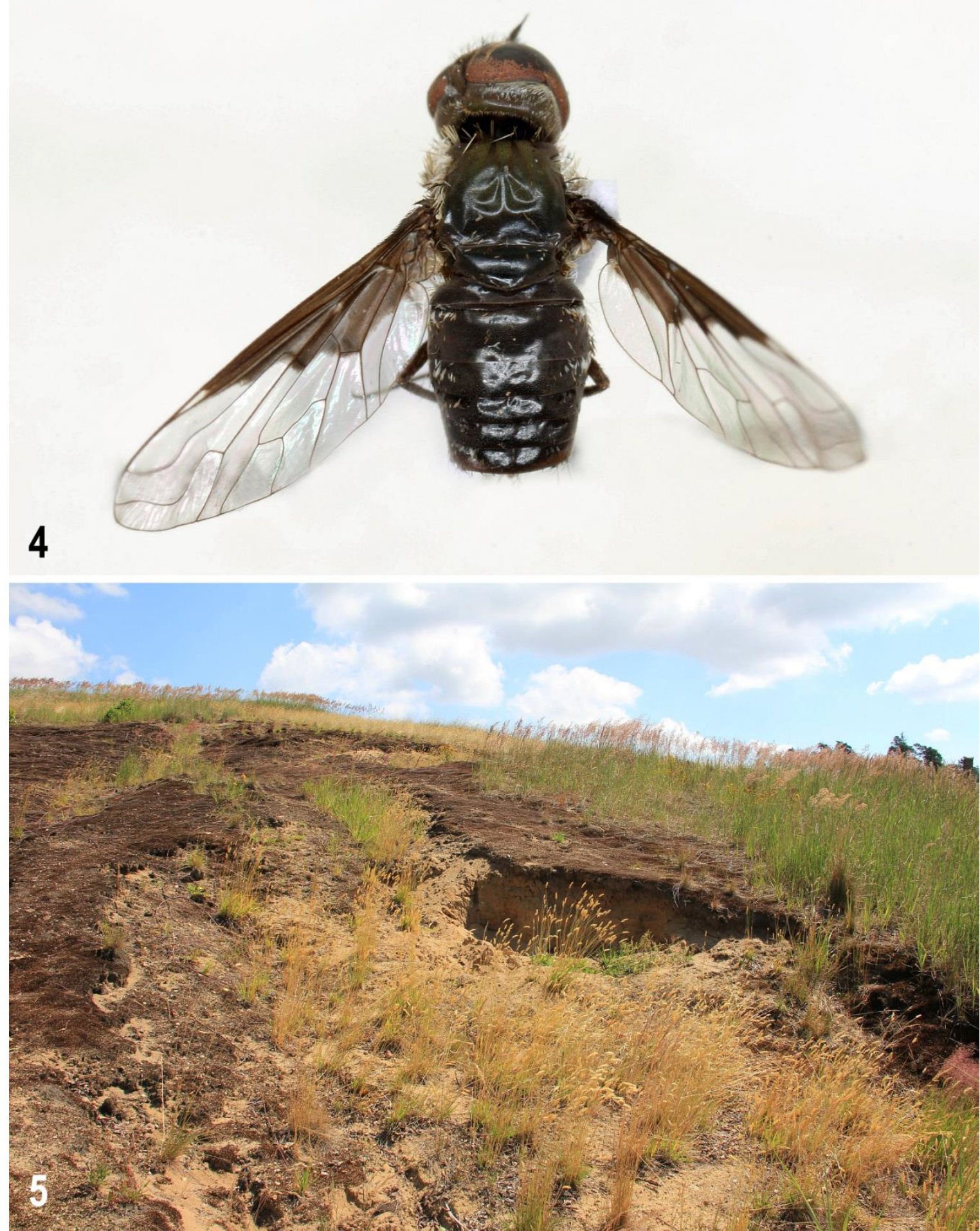

Figs 4-5: Exhyalanthrax afer (Fabricius) and its habitat. 4-E. afer, female in dorsal view (a dry-mounted voucher specimen, body length ca $5.4 \mathrm{~mm} ; \mathbf{5}$ - habitat in collecting place of the species, exposed sand in „Buben“ natural outcrop of glacial sand near Bělá (3.vii.2017). Photo by J. Roháček. 


\title{
MYTHICOMYIIDAE
}

\author{
Glabellula arctica (Zetterstedt, 1838) - psammoneutral
}

(Figs 6,7)

Material examined: CZECH REPUBLIC: N Moravia: Bělá nr. Chuchelná $0.5 \mathrm{~km}$ E, sand-pit, 4958'26"N, $18^{\circ} 09^{\prime} 05^{\prime \prime E}, 250 \mathrm{~m}$, sweeping over sand and vegetation on sand, 23.iv.2020, 10, J. Roháček leg. et det. (SMOC).

Biology: G. arctica is a minute fly associated with several species of ants of the genus Formica; for the known host species, see Andersson (1974) and Mielczarek (2018). Larvae develop inside nests of these ants where also pupae can be found (Mielczarek 2018) but their feeding habits remain unknown. Adults can be seen hovering close to insolated anthills with females entering nests for oviposition (Mielczarek 2018). In the field they are seldom found due to this behaviour and, consequently, most of the specimens in collections were collected (netted) by chance or captured in Malaise traps (Withers et al. 2017). Due to its relative rarity G. arctica is considered a vulnerable species in the Czech Republic (Bosák 2005). In Central Europe adults are recorded in IV-VIII. The species seems to live in various (both dry and humid) habitats from lowlands to mountains provided that their host ants (Formica species) are present. Mielczarek (2018) reported on its occurrence in a sandy area with dry pine forest (in Poland) and in the Podyjí National Park (Czech Republic) the majority of specimens were caught by Malaise traps in xeric forest-steppe habitat (Greathead at al. 2005). Thus, the finding of G. arctica in a sand-pit (Fig. 8), which is situated close to forest (cf. Fig. 9) with Formica spp. anthills, is not very surprising.

Distribution: This insufficiently known species has been recorded from France, Netherlands, Switzerland, Austria, Italy, Slovenia, Czech Republic, Slovakia, Poland, Denmark, Norway, Sweden, Finland, European Russia and Russian West Siberia (see Evenhuis 2002, Greathead 2013b, Withers et al. 2017, Mielczarek 2018). Records from the Czech Republic are scarce. In Bohemia it has been found in 3 localities: Fučík mine nr. Duchcov (Bosák \& Barták 2000), Šumava Mts-Jezerní slat' and Sázava (both in Evenhuis \& Bosák 1997). In Moravia there are only records from its southernmost part: Mohelno steppe (Rozkošný \& Vaňhara 1997) and the Podyjí National Park (here recorded from several localities, see Evenhuis \& Bosák 1997, Greathead et al. 2005). First record from the Czech Silesia and northern Moravia.

Comments: The species is to be classified as psammoneutral because it has no distinct affinity to sandy habitat inasmuch as it is also known from wetland areas (cf. Evenhuis \& Bosák 1997, Withers et al. 2017).

\section{THEREVIDAE}

\section{Dialineura anilis (Linnaeus, 1761) - psammobiont}

Material examined: CZECH REPUBLIC: N Moravia: Oldřišov 0.7 km N, sand-pit, 4959'51"N, 1757'48"E, 280 m, sweeping over sand \& vegetation on sand, 24.v.2019, 1§, J. Roháček leg. et det. (SMOC).

Biology: This species is known as a typical inhabitant of coastal sand dunes (Stubbs \& Drake 2014), particularly of the so-called "yellow dunes", see Howe (2010), and Nielsen et al. (2019). It is known to prefer dunes with sparse vegetation where adults (occurring in V-VII) are often observed on bare sand (Stubbs \& Drake 2014). Also Ardö (1957) reported it from marine dunes but did not consider it to be stenotopic for this habitat, apparently because it can also inhabit inland sandy habitats (as also recognized by Haarto \& Winqvist 2006). Grootaert et al. (2001) found it mainly on inland sand dunes in Belgium. The life-history of D. anilis is unknown but the presumably predatory larvae may live in sand, like those of Cliorismia rustica (see below). Based on literary records adults occur in V-VII. The specimen recorded above was swept from a small area of bare sand (see Fig. 13) in an abandoned sand-pit.

Distribution: The species is widespread in the Palaearctic Region although records from a number of European countries remain unconfirmed (see Holston 2013). Its distribution in the Czech Republic is poorly studied. Kheil (2003, unpublished bachelor thesis) summarized records obtained from the collection of K. Spitzer and some more recent published data and listed D. anilis from only a few localities in Bohemia (Hradec Králové) and from southern Moravia (Čejč, Pálava-steppe, Lednice), that from Lednice based on published record by Spitzer (1998). Therefore, Kheil (l. c.) considered it to be a rare thermophilous species in the Czech Republic. However, there are a number of old records by Vimmer (2013, as Thereva anilis) from Bohemia (Závist, Houška, Neratovice, Poděbrady, Kolín, Hradec Králové, Turnov, Hrubá Skála, Plzeň) and the species was also reported by Czižek (1906) from the vicinity of Brno in Moravia (Vranov u Brna, Brno-Černovice). These old records (if reliable) indicate that $D$. anilis could have been more frequent in the past. However, there is no previous record from Czech Silesia and northern Moravia.

Comments: The species is here considered psammobiont because of its (almost exclusive) association with sandy habitats, particularly dunes (see above). It seems to be rare and local in the Czech Republic, probably because of the limited extent of suitable inland sandy habitats. Although only one specimen in a single sand-pit was collected during the present survey it is possible that $D$. anilis lives on glacial sand also in some other localities but was not recorded due to inappropriate collecting method. 

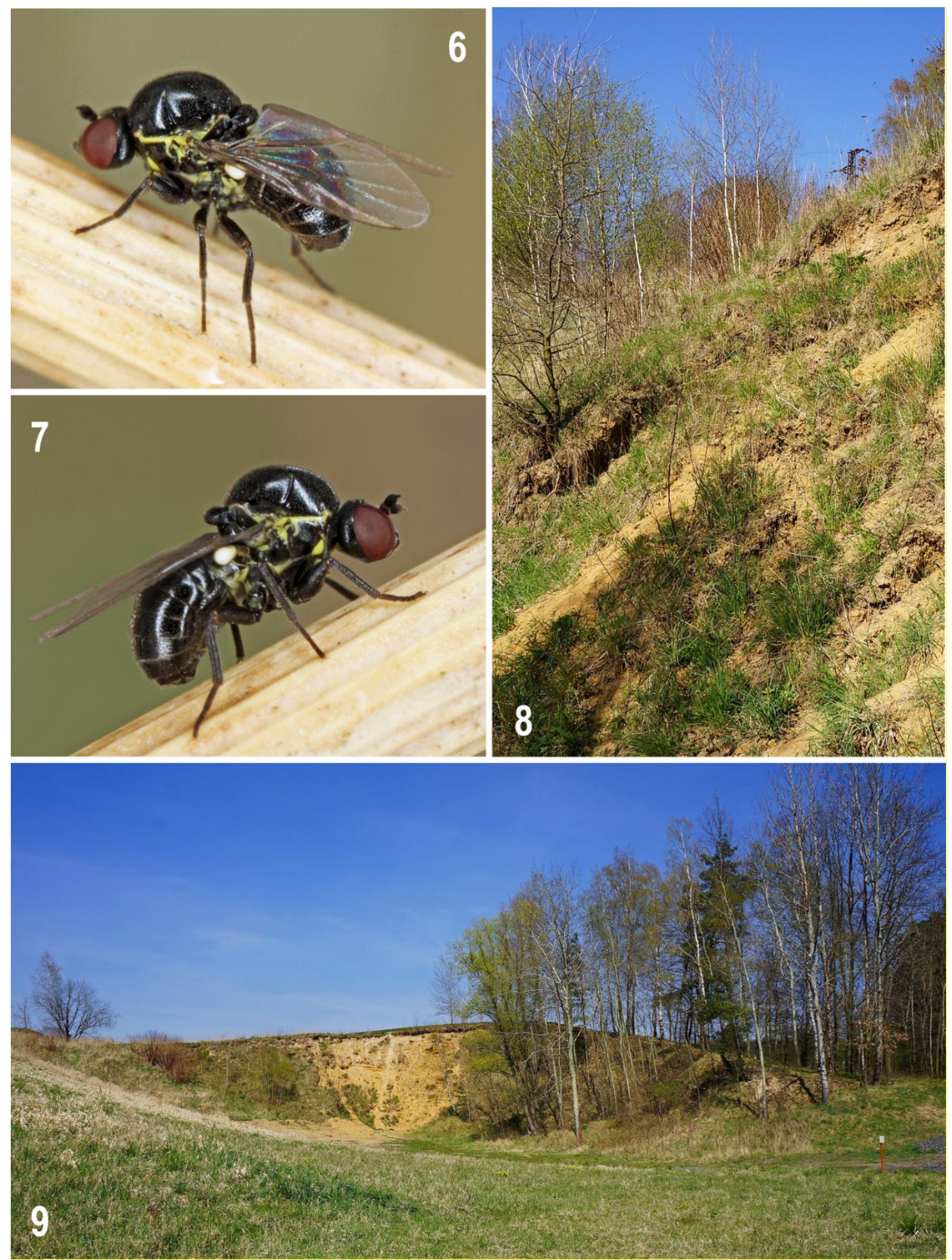

Figs 6-9: Glabellula arctica (Zetterstedt) and its habitat. 6 - G. arctica, male on grass stem, in dorsolateral view, body length ca $1.7 \mathrm{~mm} ; \mathbf{7}$ - the same, lateral view; 8 - collecting spot of the species, slope of abandoned sand-pit in Bělá; 9 - Bělá sand-pit viewed from south, with forest on its right side (23.iv.2020). Photo by J. Roháček. 
Material examined: CZECH REPUBLIC: N Moravia: Závada $1.6 \mathrm{~km} \mathrm{~S}$, sand-pit NW part, 4956'25"N, $18^{\circ} 09^{\prime} 56^{\prime \prime E}, 265$ m, sweeping over sand and sparse vegetation on sand, 24.vi.2015, 1q, J. Roháček leg. et det. (SMOC).

Biology: C. rustica is closely associated with exposed sandy sediments on riverbanks (Stubbs \& Drake 2014). Adult flies are only found occasionally but their predatory larvae can be found more readily in riverine deposits of loose sand (Hewitt \& Parker 2008). The species is not known from marine dune ecosystems (cf. Ardö 1957; Howe 2010; Nielsen et al. 2019) in contrast to another sand-preferring therevid, Dialineura anilis. On the Silesian glacial sand deposits, C. rustica was only found in the active sand-pit Závada. Interestingly, there is no running water in this sand-pit, and the only specimen of C. rustica was collected on the sand in the same habitat (Fig. 12) and on the same date as another psammophilous species associated with sandy riverbanks, viz. Curtonotum anus (Meigen, 1830), Curtonotidae (see Roháček 2016a).

Distribution: The species has a scattered distribution in western, central and eastern Europe (see Holston 2013). In the Czech Republic the distribution of C. rustica has been obscured. Although listed in the checklists by Spitzer $(1987,1997)$ for both Bohemia and Moravia, no concrete published record was found. Kheil (2003, unpublished bachelor thesis) presented it from Bohemia (Praha-Prokopské údolí, based on his own collection, without precise data) and from Moravia (Jeseníky Mts, based on a specimen from the collection of K. Spitzer). However, the latter specimen did not originate from the Jeseníky Mts but from "Freiwaldau" (= Jeseník town), 20.7.????, 1§̃, Metzenauer leg. (based on unpublished notes by K. Spitzer, personal communication with L. Dvořák, 2020). In summary, there are two records from Czech Silesia, i.e., that old (surely before World War II) from Jeseník (Jesenicko region) and the one from the Závada sand-pit in the Hlučínsko region (from the present study).

Comments: C. rustica is here classified as a psammophilous species but the distinctive association of its larvae with riverine sands (see above) would indicate that it could even be psammobiont. Its apparent rarity on glacial sand deposits might be explained by absence of riverbank habitat in the studied sand-pits and, possibly, also by the difficulty of capture of adult flies of this species.

\section{EMPIDIDAE}

\section{Empis (Coptophlebia) pilimana Loew, 1869 - psammoneutral}

Material examined: CZECH REPUBLIC: N Moravia: Oldřišov 0.7 km N, sand-pit, 4959'51"N, 1757'48"E, 280 $\mathrm{m}$, sweeping over sand and vegetation on sand, 11.vi.2019, $3 \overbrace{}^{\top} 2$; ; 3.vi.2019, 1 ; ; 4.ix.2019, 2 , all J. Roháček leg., M. Barták det. (SMOC).

Biology: Practically unknown. Adults are found on flowers. A species of the temperate and cooler parts of Europe, preferring higher altitudes in warmer areas. Rather rare species with a long flight period, ranging from the beginning of June to the end of August (Chvála 1994). For its habitat in the Oldřišov sand-pit see Fig. 15.

Distribution: Records from Austria, Czech Republic, Germany, Poland, Romania, Slovakia, Switzerland, Netherlands and southern Scandinavia are considered reliable (Engel 1938-1956, Chvála \& Wagner 1989, Goot 1989, Palaczyk 1991, Pârvu 1992, 2002, Chvála 1994, 2009, Niesiolowski 2006, Bystrowski et al. 2013a, Beuk \& Goot 2019). It can be fairly common in Central Europe, ranging south to Switzerland (Engadine) and the Romanian Carpathians (Sinaia). Although listed from Bohemia in the most recent checklist (Chvála 2009), and also all previous versions, no concrete published record was found. Apparently, the above recorded specimens are the first documenting the occurrence of E. pilimana in the Czech Republic.

Comments: Because of its unknown biology and habitat association, and also owing to its occurrence in only a single locality under study E. pilimana is here treated as psammoneutral species. The species was redescribed and a lectotype designated by Chvála (1994). According to the lectotype designation, the type locality is probably Guben (Germany).

\section{Empis (Empis) filata Loew, 1873 - psammoneutral}

Material examined: CZECH REPUBLIC: N Moravia: Závada 2 km S, sand-pit SW part, 4956'09"N, 18¹0'04"E, 270 m, sweeping over sand and sparse vegetation on sand, 12.v.2015, 10̃ , J. Roháček leg., M. Barták det. (SMOC).

Biology: Little is known about the biology of this species. Adults were reported from a meadow near forest, oak forest, rocky steppe and here also from a sand-pit (for published records see below, plus unpublished data, Barták in litt.). E. filata is probably a rare and rather thermophilous species with spring occurrence ranging from April to the middle of June. Adults are usually swept from vegetation, and occur both in mountains and lowlands, often on calcareous limestone sites. For its habitat in the Závada active sand-pit see Fig. 16. 

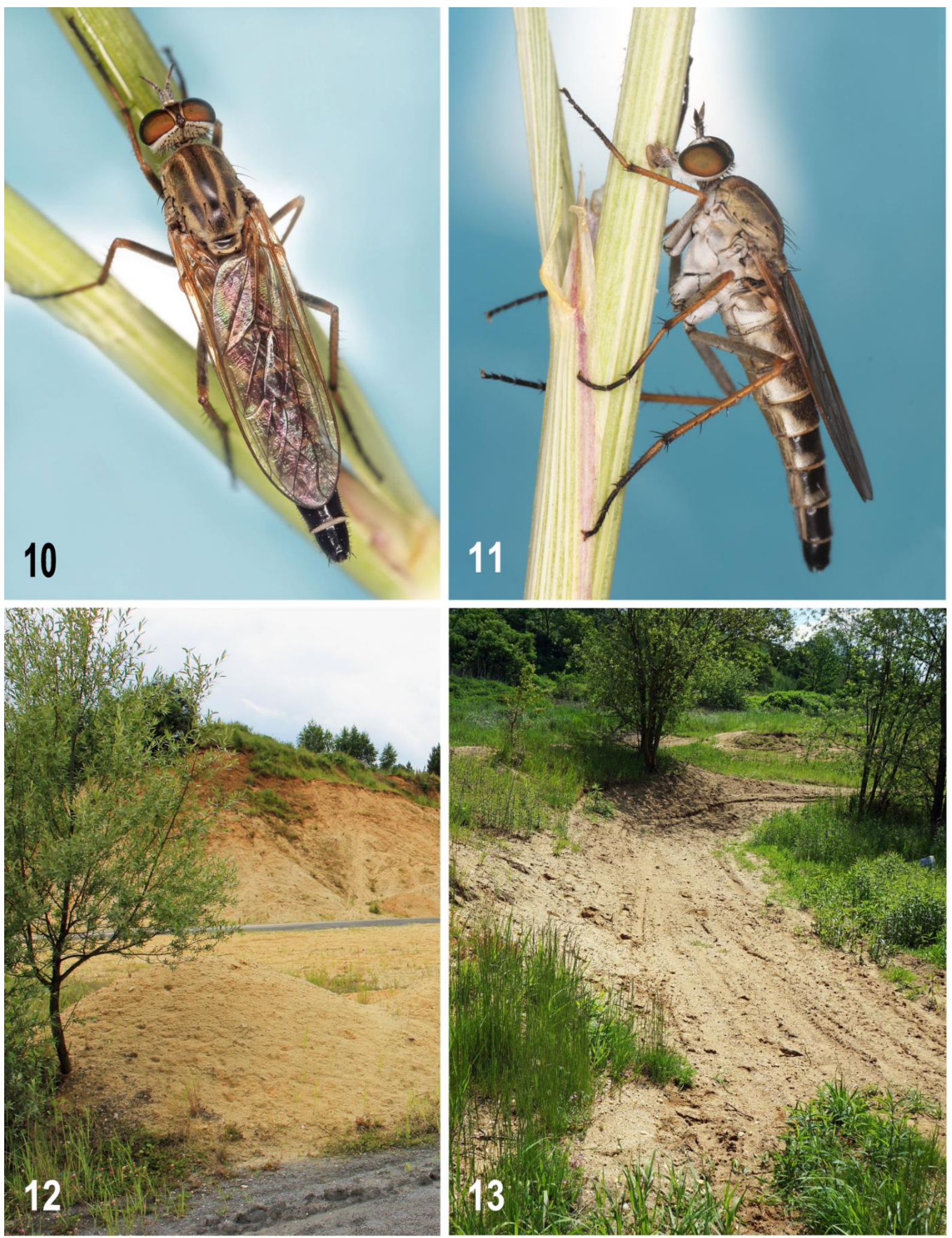

Figs 10-13: Therevidae and their habitats. 10 - Cliorismia rustica (Panzer), female in dorsal view, body length ca $11 \mathrm{~mm} ; 11$ - the same, laterally; 12 - habitat of $C$. rustica, sand heaps in NW part of the Závada sand-pit (24.vi.2015); 13 - habitat of Dialineura anilis (Linnaeus), sand places disturbed by vehicles on bottom of the Oldřišov sand-pit (24.v.2019). Photo by J. Roháček. 
Distribution: Central and southern Europe (Czech Republic, Slovakia, Poland, Romania, former Yugoslavia and Ukraine (Engel 1938-1956, Chvála \& Wagner 1989, Ceianu 1992, Niesiolowski 2006, Chvála 2009, Chvála \& Pont 2015, Bystrowski et al. 2013a, Weele et al. 2016, 2017). The northern limit of this species in Central Europe is situated in Poland (Niesiolowski 2006). The species is rare in the Czech Republic. Heřman \& Chvála (2014) noticed for E. filata only two old records from Bohemia: Radotínské údolí (from unpublished manuscript by Chvála 1991) and Sulava nr. Radotín (Chvála \& Vrtišková-Boušková 1989). Consequently, the above record is the third in the Czech Republic and first from Moravia.

Comments: Judging from various habitat records of E. filata (see above) and a single occurrence in localities under study a distinct affinity of this species to sandy sites could not be confirmed and hence, it is classified as psammoneutral.

\section{Rhamphomyia (Pararhamphomyia) murina Collin, 1926 - psammoneutral}

Material examined: CZECH REPUBLIC: N Moravia: Závada $1.8 \mathrm{~km}$ SE, sand-pit SE part, 4956'19"N, $18^{\circ} 10^{\prime} 28^{\prime \prime} \mathrm{E}, 260 \mathrm{~m}$, sweeping over sand and sparse vegetation on sand, 18.v.2017, $1 \delta^{\lambda}$; Supíkovice $1.1 \mathrm{~km} \mathrm{NE}$, $50^{\circ} 18^{\prime} 22^{\prime \prime} \mathrm{N}, 17^{\circ} 15^{\prime} 43^{\prime \prime} \mathrm{E}, 380 \mathrm{~m}$, abandoned sand-pit, S part, sweeping over sand and sparse vegetation on sand, 23.iv.2019, $2 \jmath^{\Uparrow}$, all J. Roháček leg., M. Barták det. (SMOC).

Biology: R. murina was described by Collin (1926) from Scotland and remained unrecorded for a long time until an occasional record from the Czech Republic (Bohemia: Janov n. Nisou) by Barták (1982). All other published records (Chvála \& Barták 2000) are more recent and also most of our collection records (Barták, unpublished) are from the last 20 years. This may suggest a recent increase of abundance of this species. Habitat data from collections (Barták, unpublished) and published records are as follows: arable fields, pastures, restoration of dump area, shrub-fringed riverside habitats in upland areas, fens or peatland, damp meadows etc. (see Chvála \& Barták 2000, Falk \& Crossley 2005, Grootaert et al. 2005, Brighton 2019, collection data). The great habitat diversity suggests that $R$. murina is an eurytopic species without specific habitat requirements. It was also found in two sand-pits (an active and an abandoned) under study; for its habitat in the Supíkovice sand-pit see Fig. 33. Adults occur in spring, from the end of April to the end of May, and are often caught by means of pan traps or Malaise traps.

Distribution: Great Britain, Czech Republic, Finland, Belgium (Chvála \& Wagner 1989, Grootaert et al. 2005, Chvála 2009, Kahanpää 2014, Bystrowski et al. 2013a). In the Czech Republic R. murina is only known from Bohemia (Barták 1982, Chvála \& Barták 2000). The above records (southernmost in Europe) are the first from Moravia.

Comments: Because of its large habitat tolerance (see in Biology above), R. murina is classified here as psammoneutral species.

\section{HYBOTIDAE}

Drapetis monsmargila Grootaert, Beuk \& Shamshev, 2020 - psammoneutral

(Fig. 17)

Material examined: CZECH REPUBLIC: N Moravia: Oldřišov 0.7 km N, sand-pit, 4959'51"N, 1757'48"E, 280 m, sweeping over sand \& vegetation on sand, 3.vii.2019, 1§̂, J. Roháček leg., P. Grootaert det. (SMOC).

Biology: The species was originally found on a dry calcareous grassland in southern Netherlands (Grootaert et al. 2020) where it was relatively abundant. It seems to belong to a group of rare species that are supposed to be soildwellers. However, nothing is known about its specific biology and so we refer to the paper of Michelsen \& Grootaert (2019) for the general biology of Drapetis. In the abandoned sand-pit nr. Oldřišov (Fig. 19) the species occurred together with (more abundant) D. exilis Meigen, 1822, and both were swept from vegetation on sandy ground (Fig. 18).

Distribution: Hitherto only known from the Netherlands (Grootaert et al. 2020). First record from the Czech Republic.

Comments: Although the degree of affinity of D. monsmargila to sandy soil is unclear it could be a xerophilous species, occurring in various drier habitats. Due to lack of more precise data it is classified as psammoneutral species here. The specimen found in Silesia resembles the recently described D. monsmargila in most details and differs only a little in the shape of the left surstylus (Figs 22-25) that is also shorter. We do not consider these as specific differences, and, consequently regard the above specimen as conspecific with the Dutch specimens of this species. 


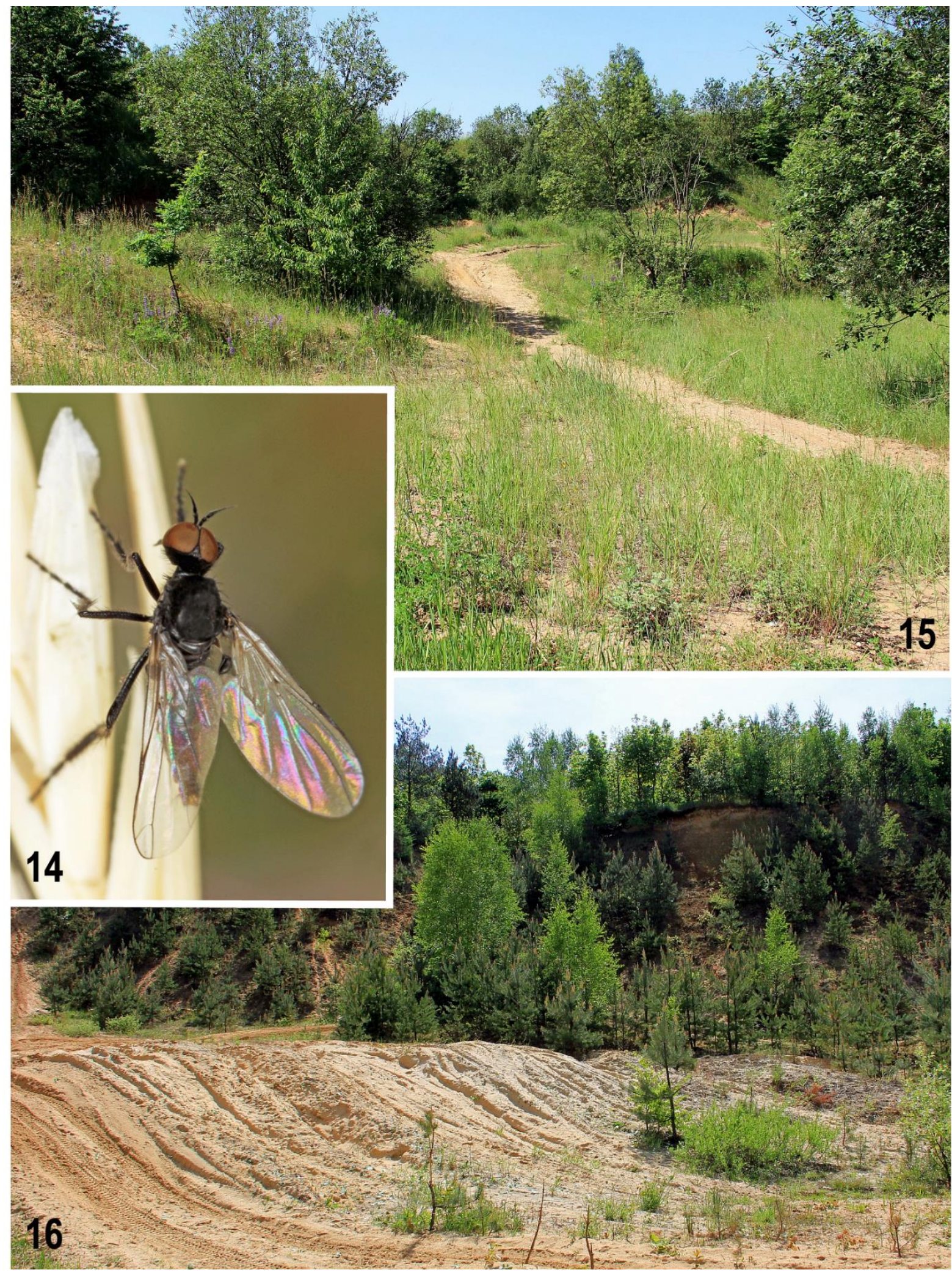

Figs 14-16: Empididae and their habitats. 14 - Empis pilimana Loew, female in dorsal view, body length ca $3 \mathrm{~mm} ; 15$ - habitat of E. pilimana, sparsely vegetated sandy bottom of the Oldřišov sand-pit (11.vi.2019); 16 - habitat of Empis filata Loew in SW part of the Závada sand-pit, with sand heaps disturbed by vehicles (12.v.2015). Photo by J. Roháček. 


\section{DOLICHOPODIDAE}

\section{Chrysotus angulicornis Kowarz, 1874 - psammoneutral}

Material examined: CZECH REPUBLIC: N Moravia: Kolnovice 1.2 km WSW, 50¹8'59"N, 17¹8'35"E, 390 m,

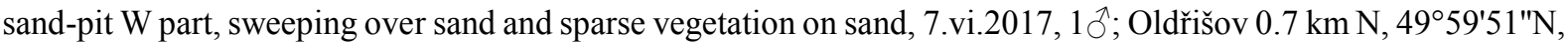

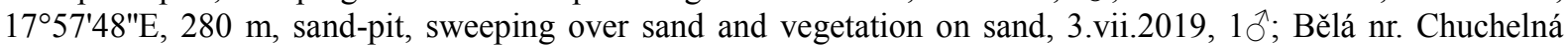
$0.5 \mathrm{~km}$ E, sand-pit, 49 $58^{\prime} 26^{\prime \prime} \mathrm{N}, 18^{\circ} 09^{\prime} 05^{\prime \prime} \mathrm{E}, 250 \mathrm{~m}$, sweeping over sand and sparse vegetation on sand, 3.vii.2017,

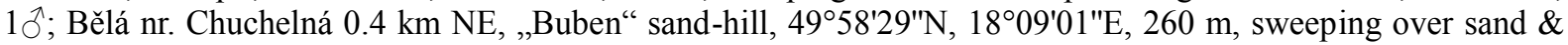
vegetation on sand, 13.vi.2019, 1§̂, all J. Roháček leg., M. Pollet det. (SMOC).

Biology: Also due to the recent taxonomic confusion (see further), only scattered information on the biology of this species is available. Olejníček (1983) reported the species as new to the Czech Republic from the edges of pools in a coniferous forest at Jevíčko (central Moravia). Drake (2020) provides a very detailed account on two soft-rock coastal cliff sites in Dorset (UK) where he collected this species during successive years. Both sites shared the same strongly disturbed limestone (base-rich) soil, fine-scale mosaic of dry and wet soil, and sparse vegetation. In Flanders (northern Belgium), the species is considered very rare as collected in 1.9\% of the investigated $5 \mathrm{~km}$ UTM squares between 1981 and 2016 (Pollet, unpublished data). It has only been recorded there from forests, grasslands and heathlands in the sandy limestone and limestone ecoregions in the western part of the region. The species was encountered in highest numbers in a ruderal grassland site at the edge of a mature deciduous forest on limestone soil, together with C. gramineus (Fallén, 1823) and C. blepharosceles Kowarz, 1874.

Distribution: This European species has been recorded from Austria, Belgium, Czech Republic, Germany, Finland, France, Hungary, Italy, Poland, Romania, Slovakia, Switzerland, Ukraine (Carpathians) (Pollet 2011), Bulgaria (Kechev et al. 2020) and the UK (England) (Drake 2020). Re-instated as valid species for the Czech Republic.

Comments: Considering the above information on habitat association and its scattered occurrence in low numbers in the glacial sand-pit habitats in this study C. angulicornis probably has no distinct preference to sandy habitats and is, therefore, treated here as psammoneutral species. Chandler (1998) considered C. angulicornis as synonym of $C$. gramineus inspired by the findings by Cole (1987). Pollet (2011) adopted this approach in the first version of the Fauna Europaea database that was published in 2004. Two years later, Negrobov \& Chandler (2006) reinstated $C$. angulicornis as a valid species on the basis of a comparison of the detailed structure of the hypopygium of this species with $C$. gramineus. This study revealed distinct differences which also corresponded with other non-genital differences between both species. This re-instatement was therefore also widely accepted (e.g., Drake 2020). The most recent Diptera checklists of the Czech Republic and Slovakia (Pollet \& Olejníček 2006; Pollet \& Suvák 2009) only include a remark on $C$. angulicornis as synonym of $C$. gramineus. The previous version (Olejníček 1997), however, listed C. angulicornis as known from both Bohemia, Moravia and Slovakia.

Cryptophlebs kerteszi Lichtwardt, 1898 - psammophilous

(Figs 26, 27)

Material examined: CZECH REPUBLIC: N Moravia: Supíkovice $1.1 \mathrm{~km} \mathrm{NE}, 50^{\circ} 18^{\prime} 22^{\prime \prime} \mathrm{N}, 17^{\circ} 15^{\prime} 43^{\prime \prime E}, 380 \mathrm{~m}$, abandoned sand-pit, S part, sweeping over sand and sparse vegetation on sand, 7.vi.2017, 3q; 9.vii.2019, 1웅

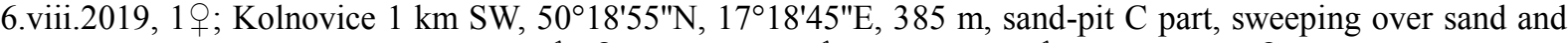

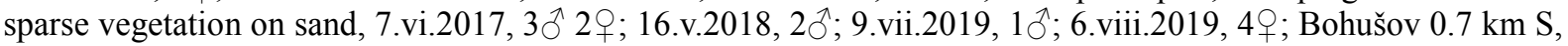
$50^{\circ} 14^{\prime} 14^{\prime \prime} \mathrm{N}, 17^{\circ} 42^{\prime} 57^{\prime \prime} \mathrm{E}, 250 \mathrm{~m}$, abandoned sand-pit, sweeping over sand and vegetation on sand, 9.vii.2019, 3 ; Oldřišov $0.7 \mathrm{~km} \mathrm{~N}, 4^{\circ} 59^{\prime} 51^{\prime \prime N}, 1^{\circ} 57^{\prime} 48^{\prime \prime} \mathrm{E}, 280 \mathrm{~m}$, sand-pit, sweeping over sand and vegetation on sand, 11.vi.2019, $1 \bigcirc^{\top} 3$ \% ; Závada $1.8 \mathrm{~km} \mathrm{SE}$, sand-pit SE part, 49 $56^{\prime} 19^{\prime \prime} \mathrm{N}, 18^{\circ} 10^{\prime} 28^{\prime \prime} \mathrm{E}, 260 \mathrm{~m}$, sweeping over sand and sparse vegetation on sand, 29.vi.2016, 1 \%; Závada $2 \mathrm{~km} \mathrm{~S}$, sand-pit SW part, 4956'09"N, 18¹0'04"E, $270 \mathrm{~m}$, sweeping sparse vegetation on sand, 17.vii.2013, 1今; sweeping over sand and sparse vegetation on sand, 29.vi.2016, $1 \bigcirc^{\Uparrow} 3$ \% ; POLAND: Godów 1.3 km ESE, sand-pit, 4955'13"N, 18²9'41"E, $230 \mathrm{~m}$, sweeping over sand and vegetation on sand, 13.6.2019, 2 , , all J. Roháček leg., M. Pollet det. (SMOC).

Biology: Parent (1938) knew this species from steppe habitats in Hungary, where it co-existed together with the entirely unrelated Dolichophorus kerteszi Lichtwardt, 1902. No other information on its ecology has been found in the literature. C. kerteszi is extremely rare in Flanders (Belgium), as collected in $0.4 \%$ of the investigated $5 \mathrm{~km}$ UTM squares between 1981 and 2016 (Pollet, unpublished data). This single site can be described as a reclaimed terrain along a large canal, featuring bare places and an overall low vegetation. The species seems to prefer bare to sparsely vegetated open habitats, often on sandy soils (for its microhabitat in sand-pits under study see Fig. 28).

Distribution: This species is known from Belgium, Hungary, Romania, Central and Southern European Russia, Serbia (Kechev et al. 2020), Spain, and Sweden; its occurrence in Eastern European Russia is considered doubtful. It has also been recorded from China (Negrobov 1991, Pollet 2011). First records for the Czech Republic and Poland. 
Comments: $C$. kerteszi is classified here as a psammophilous species. Its close affinity to sandy habitats is confirmed by current knowledge (see Biology above) as well as by its frequent occurrence on glacial sands in Silesia including southern Poland (in 6 of the 9 studied sites). C. kerteszi is easily recognized among Dolichopodidae by its distinct eye pattern (Figs 26, 27), in combination with the following features: minute size; particular wing venation, with the costal vein only reaching the end of vein $\mathrm{R}_{4+5}$, and vein $\mathrm{M}_{1+2}$ distinctly interrupted at the "bosse alaire"; and acrostichal bristles absent.
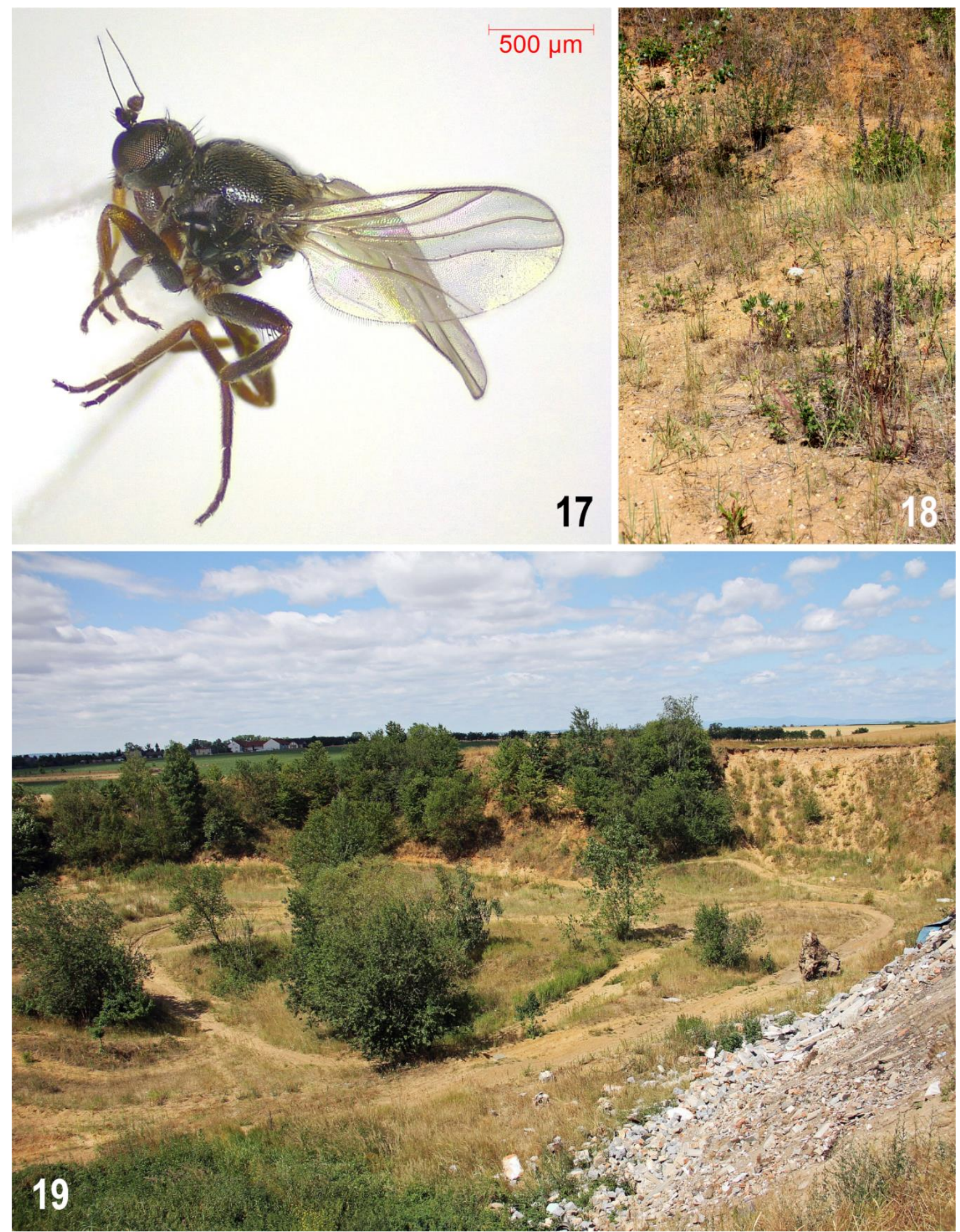

Figs 17-19. Drapetis monsmargila Grootaert, Beuk \& Shamshev and its habitat. 17 - male, with abdomen removed for dissection; 18 - microhabit of $D$. monsmargila in the Oldřišov sand-pit; 19 - the same sand-pit, viewed from east (both 3.vii.2018). Photo P. Grootaert (17) and J. Roháček (18, 19). 

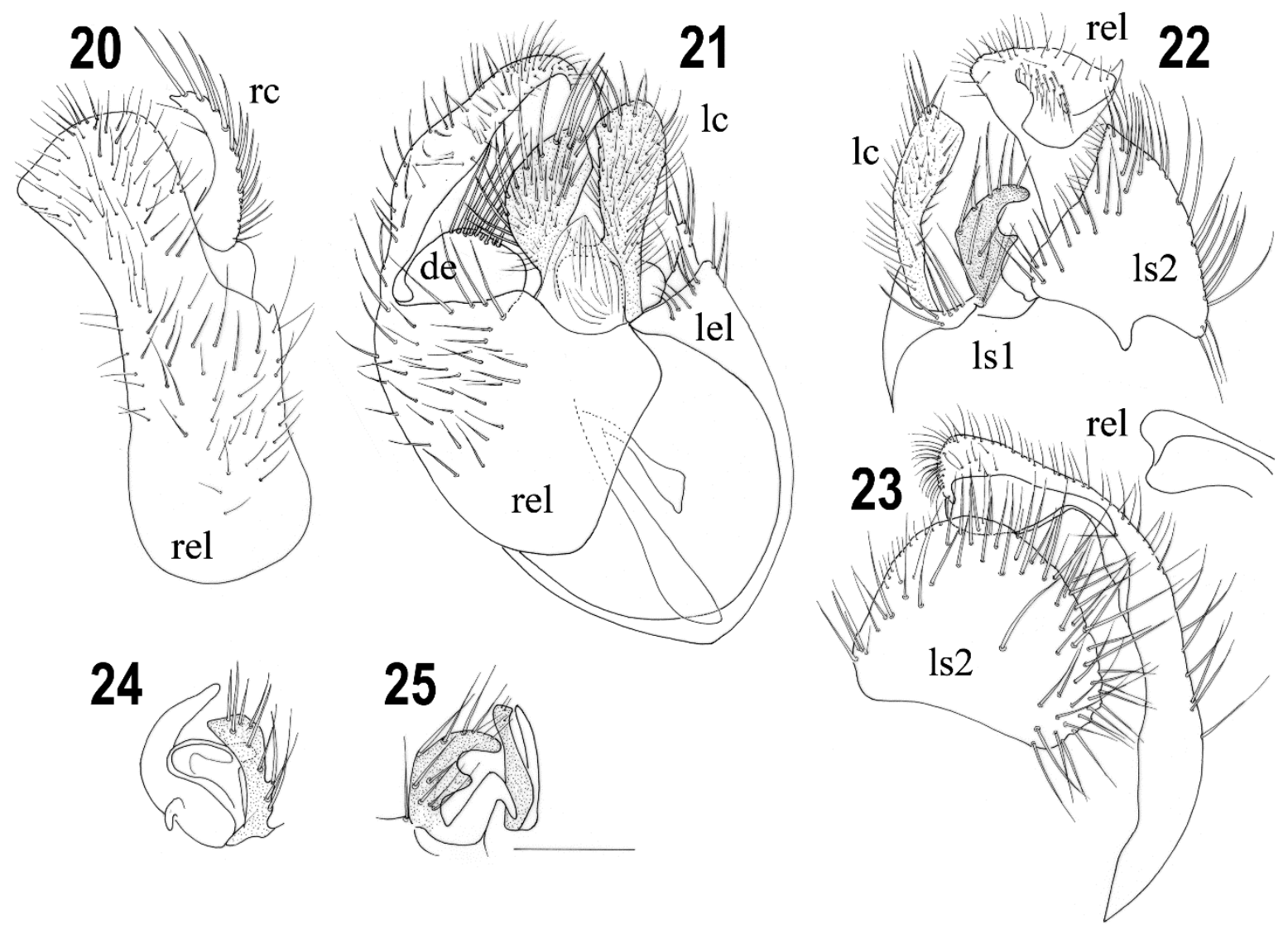

Figs 20-25. Drapetis monsmargila Grootaert, Beuk \& Shamshev, male terminalia (Oldřišov sand-pit). 20 - right epandrial lamella in dorsal view and right cercus in lateral view; 21 - epandrium dorsally; 22 - left cercus, left surstyli and lateral side of right epandrial lamella; 23 - left surstylus and side of right epandrial lamella; 24 - left surstylus (dark) with unidentified underlying structures; 25 - left surstylus in lateral view (dark) with unidentified appendages. Abbreviations: de - dorsal extension of the right epandrial lamella; e - epiproct; lc - left cercus; lel left epandrial lamella; 1s1: - l eft surstylus 1; ls2 - left surstylus 2; rc - right cercus; rel - right epandrial lamella. Scale $0.1 \mathrm{~mm}$. (P. Grootaert del.).

\section{Medetera annulitarsus von Roser, 1840 - (probably) psammophilous}

Material examined: CZECH REPUBLIC: N Moravia: Oldřišov 0.7 km N, 4959'51"N, 1757'48"E, 280 m, sand-

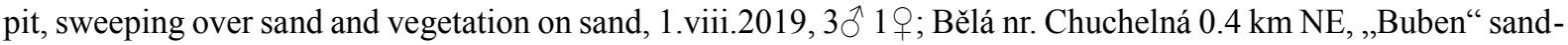
hill, 49॰58'29"N, 1809'01"E, 260 m, sweeping over sand \& vegetation on sand, 11.vii.2019, 1 \%; 8.viii.2019, 19;

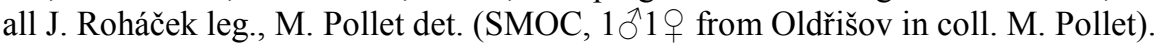

Biology: The ecology of this species is entirely unknown. In the past, this species has been assigned to the subgenus Oligochaetus Mik, 1878 together with Medetera micacea Loew, 1857, M. mixta Negrobov, 1967 and M. plumbella Meigen, 1824, on the basis of a single pair of scutellar bristles. Despite the fact that this group represents a paraphyletic clade (Pollet et al. 2011), the three above mentioned species mainly occur in dry to moderately wet, open sandy biotopes like coastal dunes and heathlands. They thus differ from most of the other congeners which are mostly found on tree trunks. It is quite likely that $M$. annulitarsis exhibits a similar ecological niche. For the habitat of this species in the Oldřišov sand-pit, see Fig. 29.

Distribution: This mainly central European species has thus far been reported from Austria, Czech Republic, Germany, Hungary, Poland, Romania, Slovakia and Spain. Slovak records of this species are based on specimens collected in Bojnice and Ivanka pri Dunaji (Olejníček \& Kozánek 1989). The record from the Czech Republic (Bohemia), however, proves invalid: indeed, Olejníček \& Kozánek (1989) erroneously mentioned that M. dichaeta Kowarz, 1877 (later synonymized with M. annulitarsus) was described from Bohemia. The Swedish record listed by Negrobov (1991) could not be confirmed by a specimen of this species in one of the public Swedish collections and was subsequently removed from the Swedish checklist (Persson et al. 2019). Likewise, Finnish records proved to be based on misidentifications (Kahanpää 2014). Yang et al. (2006) also listed the species from France which was later copied by Negrobov \& Naglis (2016). However, those authors were unable to reconstruct how this record 
came about and since no detailed information nor specimens support this record, we consider it invalid as well. First valid records for the Czech Republic.

Comments: The known biological data suggest a possible association of this species with sandy habitats, and therefore it can be treated as a probably psammophilous species. M. annulitarsus is incorrectly listed as a synonym of Medetera diadema (Linnaeus, 1767) by Becker (1917-2018) and Parent (1938), and was later synonymized with M. dichaeta Kowarz, 1877 by Denninger (1950). It is treated as a valid species by Negrobov (1991), Yang et al. (2006) and Pollet (2011). It can be quite easily separated from related species by the combination of two black prothoracic bristles, metallic clypeus and mainly dark femora and otherwise largely pale legs.

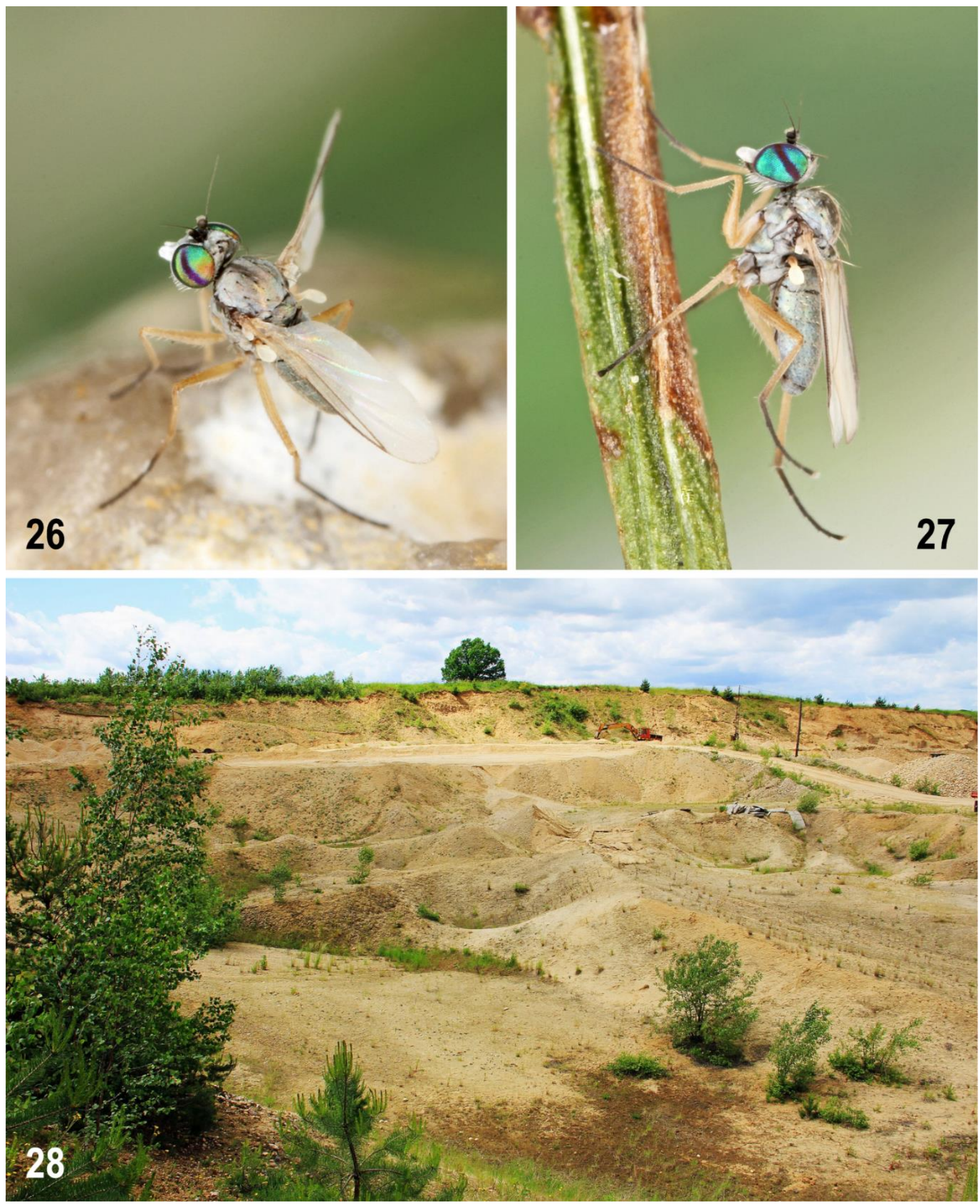

Figs 26-28. Cryptophlebs kerteszi Lichtwardt and its habitat. 26 - male, subdorsally, on small pebble, body length ca $1.8 \mathrm{~mm} ; 27$ - male, laterally, on small twig; 28 - habitat of $C$. kertezsi, bottom of the central part of the Kolnovice active sand-pit viewed from north (17.vi.2017). Photo J. Roháček. 


\section{Medetera grunini Negrobov, 1966 - (probably) psammophilous}

Material examined: CZECH REPUBLIC: N Moravia: Kolnovice $1 \mathrm{~km} \mathrm{SW,} \mathrm{50} 18^{\prime} 55^{\prime \prime N}, 17^{\circ} 18^{\prime} 45^{\prime \prime} \mathrm{E}, 385 \mathrm{~m}$,

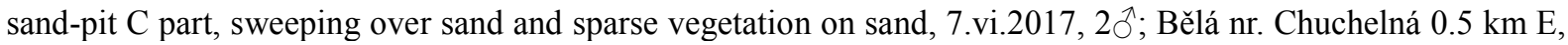
sand-pit, 4958'26"N, 1809'05"E, 250 m, sweeping over steppe meadow, 3.vii.1996, 1q, all J. Roháček leg., M. Pollet det. (SMOC).

Biology: Since the discovery of the type specimens of this species, it had not hitherto been detected again. Hence, its ecology is entirely unknown. This species also has only one pair of scutellar bristles and as the previous species, it can be assumed that also $M$. grunini has a preference for bare to sparsely vegetated, open biotopes on sandy soils. Its habitat on the bottom of the Kolnovice sand-pit (shared with other Dolichopodidae like C. kerteszi) is shown in Fig. 28.

Distribution: Thus far this species was only known from the Mangyshlak Peninsula in Kazakhstan (Negrobov 1991), an area between desert and semi-desert with a harsh continental dry climate. First record for the Czech Republic and the European subcontinent.

Comments: Considering the above information, this apparently thermophilous species is likely to be associated with sands, and, therefore, classified as probably psammophilous. Specimens of this Medetera species collected in glacial sand-pit sites in the Czech Republic run in the key by Negrobov \& Naglis (2016) to M. grunini, matching all features in the respective couplet. Especially the flattened bristles on the fore coxae were distinct and separate it from the related and equally pale-legged M. plumbella. The verification of their identity by checking the type specimens of M. grunini currently deposited in the Zoological Museum of the Zoological Institute of the Russian Academy of Sciences (Saint Petersburg, Russia) is ongoing.

\section{Medetera lorea Negrobov, 1967- psammoneutral}

Material examined: CZECH REPUBLIC: N Moravia: Supíkovice $1.1 \mathrm{~km} \mathrm{NE}, 50^{\circ} 18^{\prime} 22^{\prime \prime} \mathrm{N}, 1^{\circ} 15^{\prime} 43^{\prime \prime} \mathrm{E}, 380 \mathrm{~m}$, abandoned sand-pit, S part, sweeping over sand and sparse vegetation on sand, 9.vii.2019, 1§ึ, J. Roháček leg., M. Pollet det. (SMOC).

Biology: Although it is quite hard to define the ecological profile of $M$. lorea, based on the 50 specimens collected in Flanders (northern Belgium), it seems to prefer rather open park landscapes (also gardens) on rather dry sandy soils. It is considered rare in this region as recorded in 3.3\% of the investigated 5km UTM squares between 1981 and 2016 (Pollet, unpublished data). The Swedish Malaise Trap Project (SMTP) (Persson et al. 2019, Karlsson et al. 2020, Ronquist et al. 2020) produced over 250 specimens of this species from all over the country. M. lorea was encountered in largest numbers in grasslands, heathlands and disturbed habitats which concurs well with the observations in Belgium.

Distribution: Pollet (2011) only lists reliable records from Central European Russia and Belgium, and a doubtful record from Eastern European Russia. More recently, the species was also recorded from Germany (Bellstedt \& Stark 2006), Switzerland (Naglis \& Negrobov 2014), Croatia (Pollet \& Ivkovic 2018), and Sweden (Persson et al. 2019). First record for the Czech Republic.

Comments: The above information does not suggest an association of this species with sandy biotopes. Also considering only the single record from the glacial sand deposits under study, it is treated as psammoneutral. M. lorea can be separated from two other pale-legged European species of the Medetera apicalis (Zetterstedt, 1843) species group, i.e., Medetera pallipes (Zetterstedt, 1843) and Medetera rufipes Negrobov, 1974, by its smaller stature (wing length about $1.8 \mathrm{~mm}$ ), a $\mathrm{CuAx}$ ratio of about 2.0, and yellow mid and hind tibiae which are darker on their anterior face. Also the hypopygium in males of all three species is distinctive. The two latter species have a wing size over $2.0 \mathrm{~mm}$ and a CuAx ratio of at least 2.5. Mid and hind tibiae in M. pallipes are entirely yellow, and brownish yellow with infuscate basal and apical part in M. rufipes. M. lorea might be substantially more common than the current data suggest. The best methods to collect this species are Malaise traps, hand collecting and white pan traps (Pollet, unpublished data).

\section{Melanostolus melancholicus (Loew, 1869) - psammophilous}

Material examined: CZECH REPUBLIC: Dolní Lutyně 1.2 km N, sand-pit, 4954'34"N, 18²5'33"E, 210 m, sweeping over sandy lake shore, 13.vi.2019, 2ð, J. Roháček leg., M. Pollet det. (SMOC).

Biology: M. melancholicus can be described as a psammophilous species of bare and sparsely vegetated sunny and shallow borders of pools and ponds on sandy soils, often in forested landscapes. In Ireland it has been encountered in old birch forest on valley bog (Speight \& Meuffels 1989) and on moorland in Yorkshire, UK (Crossley 2007). The species does not seem to be restricted to peatbogs as proven by its discovery in wet flushes on the bottom of an active limestone quarry (Gibbs 1988) and in soft-rock coastal cliff sites on limestone soil (Drake 2020) in the UK. Máca (2006) calls M. melanostolus a thermophilous species of open sands in the Třebon̆ 

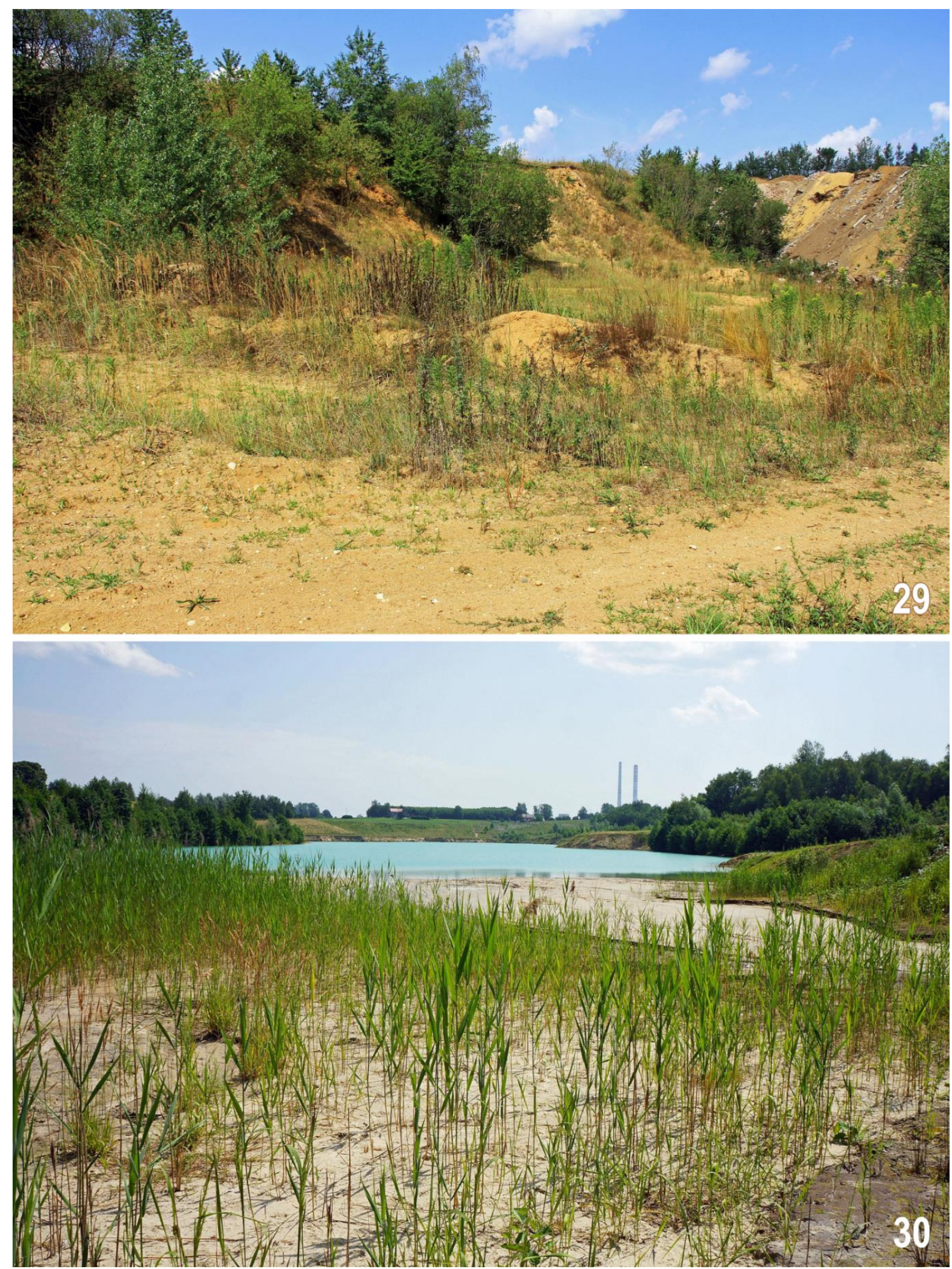

Figs 29-30. Habitats of Dolichopodidae in sand-pits. 29 - habitat of Medetera annulitarsus von Roser, sparsely vegetated bottom of the Oldřišov sand-pit, viewed from southwest (1.viii.2019); 30 - habitat of Melanostolus melancholicus (Loew), sandy western shore of the artifical lake with sparse Phragmites growth in the Dolní Lutyně active sand-pit (13.vi.2019). Photo J. Roháček. 
region in southern Bohemia (Czech Republic). In Flanders (northern Belgium), the species occurs both in the western and eastern part but is currently only recorded from the sandy limestone, limestone and Campines ecoregions, while missing in the coastal and polder ecoregions. In the abovementioned ecoregions, it is entirely confined to heathlands with fens and considered rare as encountered in $2.6 \%$ of the investigated $5 \mathrm{~km}$ UTM squares between 1981 and 2016 (Pollet, unpublished data). The record from the Dolní Lutyně active sand-pit, i.e., the only sand-pit with water reservoirs, and its occurrence there on the shore of an artificial lake (Fig. 30) confirms its ecological profile given above.

Distribution: This species has been recorded from Belgium, Czech Republic (Bohemia, see Máca 2006), Finland, France, Hungary, Ireland, The Netherlands, Romania, Northwestern and Southern European Russia (Northern Caucasus), Sweden, UK (England), former Yugoslavia, and the Near East of Asia. The record from Kenya (Negrobov 1991) is considered doubtful. First record for Moravia.

Comments: On the basis of current biological knowledge, M. melancholicus is considered a psammophilous species despite single record from glacial sand localities under study. The entirely black coloured M. melancholicus is easily recognized as a member of the diaphorine subfamily, especially in the male, by the enlarged pulvilli in the fore and mid legs, and the macrochaetae on the genital capsule. In contrast to males of Diaphorus Meigen, 1824 with eyes touching on the frons, the frons in M. melancholicus is even wider than the face. Females of M. melancholicus can most easily be distinguished from those of the equally dark and often sympatric Diaphorus nigricans Meigen, 1824 by the presence of a black halter (which is pale in D. nigricans).

\section{Sciapus basilicus Meuffels \& Grootaert, 1990 - (probably) psammophilous}

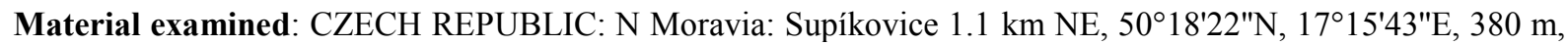
abandoned sand-pit, S part, sweeping over sand and sparse vegetation on sand, 7.vi.2017, $4 \hat{\diamond^{\lambda}} 3$ ㅇ; 16.v.2018, $4 \hat{\jmath}$

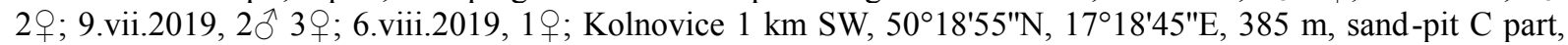

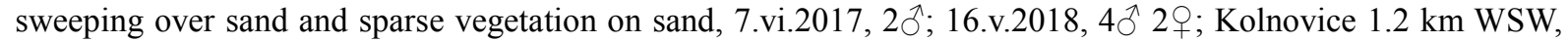
$50^{\circ} 18^{\prime} 59^{\prime \prime} \mathrm{N}, 17^{\circ} 18^{\prime} 35^{\prime \prime} \mathrm{E}, 390 \mathrm{~m}$, sand-pit W part, sweeping over sand and sparse vegetation on sand, 7.vi.2017,

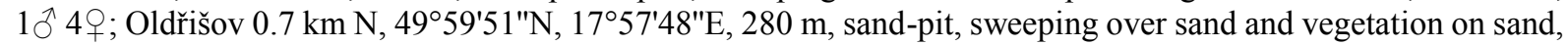
3.vii.2019, 1; Bělá nr. Chuchelná $0.5 \mathrm{~km} \mathrm{E}$, sand-pit, 49 $58^{\prime} 26^{\prime \prime} \mathrm{N}, 18^{\circ} 09^{\prime} 05^{\prime \prime} \mathrm{E}, 250 \mathrm{~m}$, sweeping over sand and sparse vegetation on sand, 3.vii.2017, $10^{\Uparrow} 2$ \%; Závada $1.6 \mathrm{~km} \mathrm{~S}$, sand-pit NW part, 4956'25"N, 1809'56"E, 265

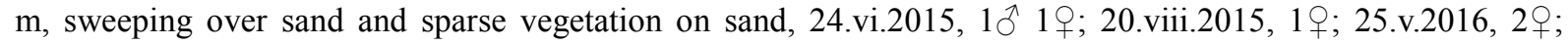
29.vi.2016, 1 \%; 18.v.2017, 1 ; Z Závada 2 km S, sand-pit SW part, 4956'09"N, 18¹0'04"E, 270 m, sweeping over

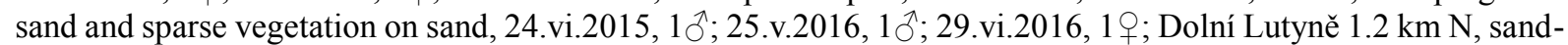
pit, 4954'34"N, 18²5'33"E, 210 m, sweeping over sandy lake shore, 8.viii.2019, 1 \%; POLAND: Godów 1.3 km ESE, sand-pit, 49 $55^{\prime} 13^{\prime \prime N}, 18^{\circ} 29^{\prime} 41^{\prime \prime E}, 230 \mathrm{~m}$, sweeping over sand and vegetation on sand, 16.5.2019, 1ㅇ, all J. Roháček leg., M. Pollet det. (SMOC, $1 \delta^{\Uparrow}$ from Supíkovice in coll. M. Pollet).

Biology: The ecology of this species is hardly known. Meuffels \& Grootaert (1990) did not mention information on the habitat of the type series of the species and neither did Grichanov \& Negrobov (2014). The species has recently been encountered in fairly large numbers on a tree trunk of a dead willow in a marshland environment (Pollet, unpublished data). In this way, it seems similar to other European species in this genus like e.g., Sciapus platypterus (Fabricius, 1805), S. wiedemanni (Fallén, 1823) and S. zonatulus (Zetterstedt, 1843) (Pollet \& Grootaert 1987). In contrast, species like S. contristans (Wiedemann, 1817) and S. maritimus Becker, 1918 are mainly found on open, bare to sparsely vegetated sandy soils but have not been encountered during the current study. On the contrary, $S$. basilicus proved to be relatively common in glacial sand sites, while congeners like S. albifrons (Meigen, 1830), S. bellus (Loew, 1873) and S. platypterus were only collected as singletons. S. basilicus can be netted regularly on sparsely vegetated sand on the bottom of sand-pits (cf. Figs 28, 33).

Distribution: The species has been recorded from Austria, Denmark, Finland, Germany, the Netherlands, Norway, Northwestern European Russia, Northern Caucasus (Krasnodar), Romania, Sweden, Switzerland, and the UK (Grichanov \& Negrobov 2014). First records for the Czech Republic and Poland.

Comments: Due to its frequent and relatively abundant occurrence in most of the sand deposits under study $S$. basilicus might have a closer affinity to sandy habitats than previously assumed and is, therefore, classified here as a probably psammophilous species.

\section{Schistostoma truncatum (Loew, 1864) - psammobiont}

(Figs 34, 35)

Material examined: CZECH REPUBLIC: N Moravia: Supíkovice $1.1 \mathrm{~km} \mathrm{NE}, 50^{\circ} 18^{\prime} 22^{\prime \prime} \mathrm{N}, 1^{\circ} 15^{\prime} 43^{\prime \prime E}, 380 \mathrm{~m}$, abandoned sand-pit, S part, sweeping over sand and sparse vegetation on sand, 16.v.2018, 19; Závada $1.6 \mathrm{~km} \mathrm{~S}$, sand-pit NW part, 49 $56^{\prime} 25^{\prime \prime} \mathrm{N}, 18^{\circ} 09^{\prime} 56^{\prime \prime} \mathrm{E}, 265 \mathrm{~m}$, sweeping over sand and sparse vegetation on sand, 18.v.2017, 1 , , all J. Roháček leg., M. Barták det. (SMOC). 

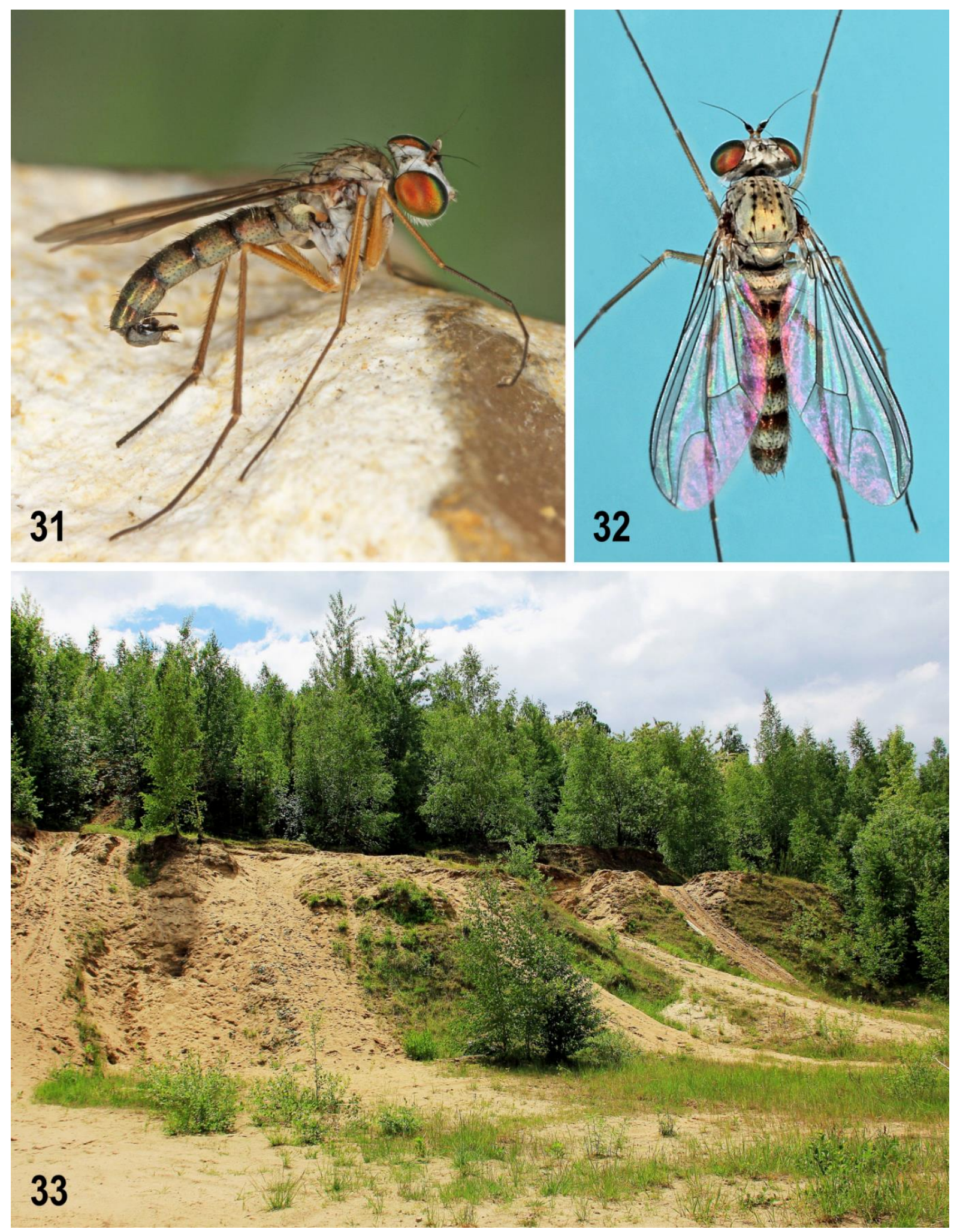

Figs 31-33. Sciapus basilicus Meuffels \& Grootaert and its habitat. 31 - male, laterally, on small pebble, body length ca $4.5 \mathrm{~mm} ; \mathbf{3 2}$ - male, dorsally; $\mathbf{3 3}$ - habitat of S. basilicus, sandy bottom in southern part of the Supíkovice abandoned sand-pit viewed from northeast (16.v.2018). Photo J. Roháček. 
Biology: Nothing is known about immature stages of Schistostoma species, a swarming or hovering habit has not been observed. However, the adults exclusively inhabit warm sandy biotopes, prefer southern areas and do not penetrate northwards beyond $60^{\circ} \mathrm{N}$ (Chvála 1987, Shamshev 1999, Shamshev \& Sinclair 2006, Gatt 2014). It is supposed that larvae of this genus are predaceous, living in sand or sandy soil (Chvála 1987, Barták \& Bartáková 2004). Adults of most other Microphorinae species are also predatory while some of them are also efficient pollinators (Barták \& Bartáková 2004). Schistostoma species have always been collected in dry sandy habitats, in deserts, sandy coasts, in coastal saline biotopes, and were often swept from xerophilous desert plants or found in salt marshes (Chvála 1987, Shamshev 1993). They are rarely found in collections, because the flies are minute, with a body size not exceeding 2-3 mm (Shamshev 1993), and of a grey colour (cf. Figs 34, 35) making them hard to spot in the field. The above general characteristics are also true for $S$. truncatum. The majority of known specimens were collected in Switzerland on sandy ground in the transition zone between bare sand and vegetation, on sandy pathways in pine forests or on Stipa vegetation, but they were never found on sand near a waterline (Merz 1998). Also Loew (1864) found type female(s) on "sandigen Feldern" (sandy fields). S. truncatum has been collected in two localities on glacial sand deposits under study, on sand with very sparse spontaneous vegetation (see Figs 33 and 36). Adults can sometimes be abundant (Merz 1998), but are generally rare (Chvála 1987) which is also true for the area under study. Adults are active from VI to VII (Chvála 1987, Merz 1998).

Distribution: Central and NE Europe. The only reliable published records are from Switzerland, Germany (Bavaria), Poland (Silesia) and NE European Russia; see Chvála (1987), Merz (1998), Shamshev (1999), and Bystrowski et al. (2013b). The northernmost known record is from the Luga district in the Saint-Petersburg province, Russia (Shamshev 1999). S. truncatum was described by Loew (1864, as Microphorus) from Polish Silesia and its type locality is "Karlowitz" (based on lectotype designation by Chvála 1987). Interestingly, the locality "Karlowitz" (= now Karłowice Wielkie), is situated only $26 \mathrm{~km} \mathrm{~N}$ of the Supíkovice sand-pit and it also lies in an area of glacial sand deposits. First records from the Czech Republic.

Comments: Because of its (almost exclusive) association with sandy habitats $S$. truncatum is considered a psammobiont species. The genus Schistostoma was formerly included in the small family Microphoridae (Chvála 1983), but after phylogenetic analysis its status was converted to a subfamily of the family Dolichopodidae (Sinclair \& Cumming 2006). A total of sixteen Palaearctic species of this genus are known (Chvála 1987, Shamshev 1991, 1993, Pârvu \& Popescu-Mirceni 2007, Gatt 2014) of which only S. truncatum and S. thalhammeri Chvála, 1987 occur in Central Europe. For the redescription of S. truncatum see Chvála (1987).

\section{SYRPHIDAE}

\section{Paragus (Pandasyophthalmus) constrictus Šimić, 1986 - psammophilous}

Material examined: CZECH REPUBLIC: N Moravia: Supíkovice $1.1 \mathrm{~km} \mathrm{NE}, 50^{\circ} 18^{\prime} 22^{\prime \prime} \mathrm{N}, 1^{\circ} 15^{\prime} 43^{\prime \prime E}, 380 \mathrm{~m}$,

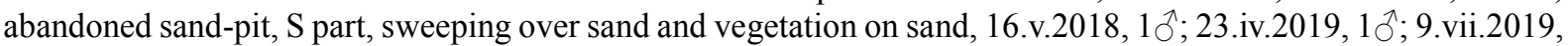

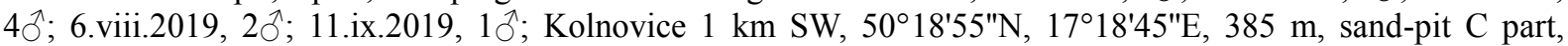

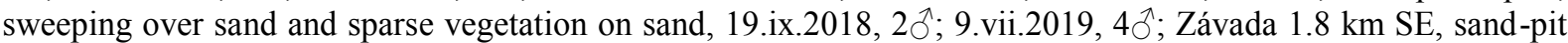

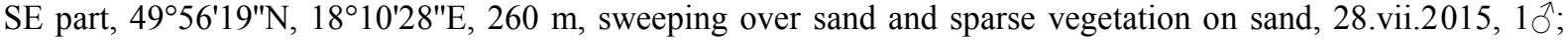
Dolní Lutyně $1.2 \mathrm{~km} \mathrm{~N}$, sand-pit, 49 $54^{\prime} 34^{\prime \prime} \mathrm{N}, 18^{\circ} 25^{\prime} 33^{\prime \prime E}, 210 \mathrm{~m}$, sweeping over sand and vegetation on sand,

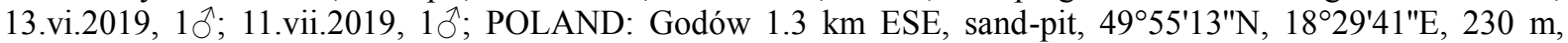
sweeping over sand \& sparse vegetation on sand, 11.vii.2019, 2ð; 8.viii.2019, $3 \hat{\jmath} ; 16.1 x .2019,1 \delta$, all J. Roháček leg., L. Mazánek det. (SMOC).

Biology: This species inhabits coastal dune systems and some other open ground sunny and sparsely vegetated habitats such as rocky limestone karsts and river banks and shores of other aquatic bodies that have sandy and calcareous deposits present, also in unimproved alpine pastures in the Alps (Speight 2018, Speight \& Chandler 1995, Haarto 2014, Bartsch et al. 2009b). The flight period of adults ranges from May to September. They can be found flying close to the ground among low sparse vegetation and occasionally resting on leaves and visiting white umbellifers (e.g. Crithmum maritimum) and also yellow flowers of Dasiphora fruticosa, Potentilla erecta, and Ranunculus (Speight 2018, Bartsch et al. 2009b). The pre-imaginal stages of the species have not been described (Speight 2018); however, it is known that larvae of this genus live as predators of aphids on low-growing herbs. Torp (1994) mentions the findings of larvae of 'Paragus tibialis' at the stem of Hypochaeris radicata in a coastal area in Denmark. This rearing record almost certainly belongs to P. constrictus judging from distribution maps of both species in Denmark by Bygebjerg (2004). In the area under study P. constrictus has been recorded from 5 (out of 9) localities. For its habitat in active and abandoned sand-pits see Fig. 28 and Figs 33 and 37, respectively.

Distribution: The species is known from southern Scandinavia, Ireland, Spain, France and across Central and Eastern Europe to the Crimean Peninsula. Outside Europe, it has been recorded also in Asian Turkey and Asian Russia (Speight 2018, Bartsch et al. 2009b). First records from the Czech Republic. 

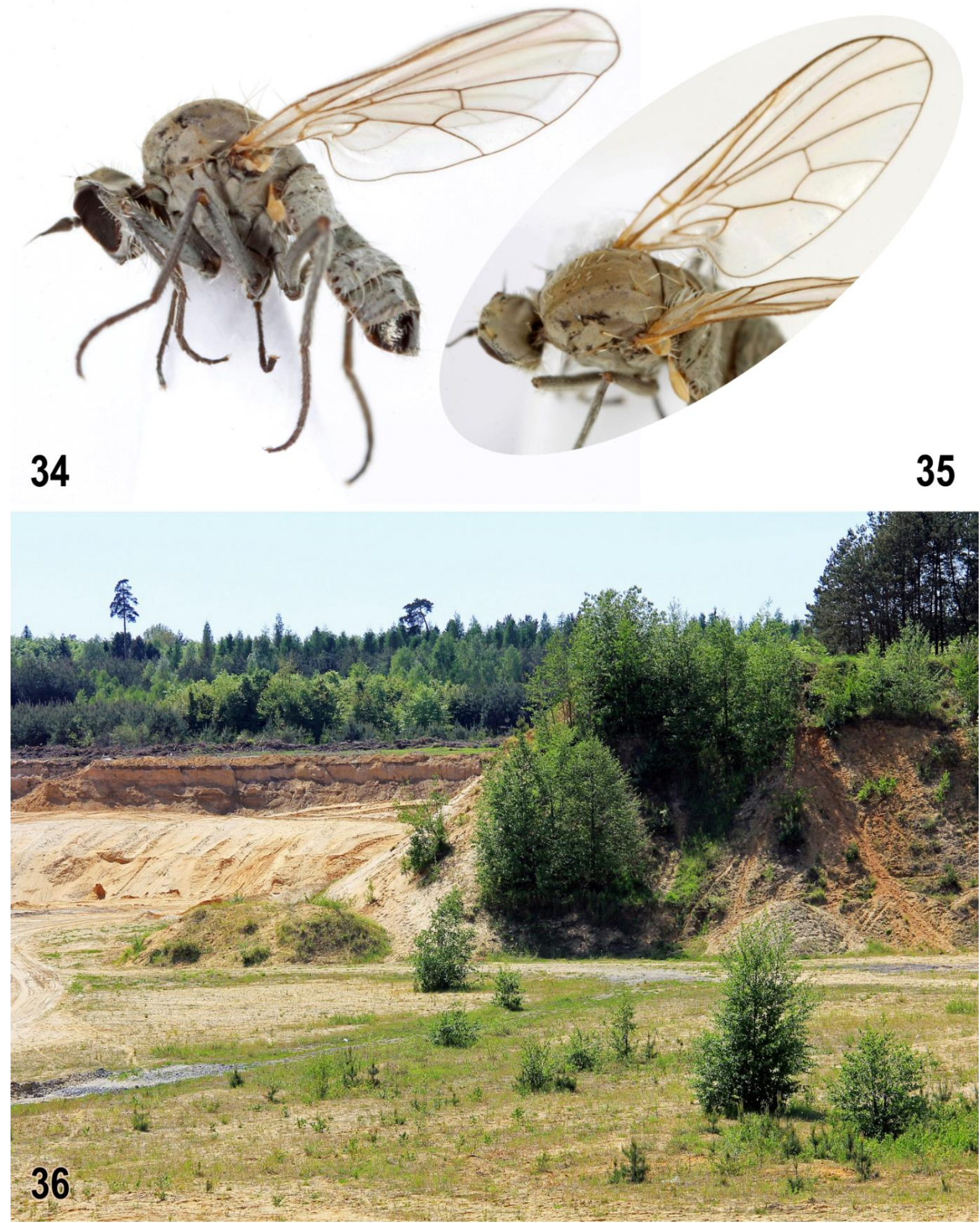

Figs 34-36. Schistostoma truncatum Loew and its habitat. 34 - female, dry mounted voucher specimen from Supíkovice, laterally, body length ca $2.8 \mathrm{~mm} ; \mathbf{3 5}$ - the same, subdorsally; $\mathbf{3 6}$ - habitat of $S$. truncatum, sandy bottom in northwestern part of the Závada active sand-pit viewed from northeast (18.v.2017). Photo J. Roháček. 
Comments: The species seems to be psammophilous or almost psamnobiont because relatively numerous stable populations of this species are found probably only on coastal dunes and similar habitats (Haarto 2014, Bartsch et al. 2009b). P. constrictus was poorly understood for a long time inasmuch as it was confused with Paragus tibialis (Fallén, 1817), see Haarto (2014) and Speight \& Chandler (1995). P. tibialis had been recorded from various regions of the Czech Republic (e.g. Kowarz 1885, Vimmer 1913, Rozkošný \& Vaňhara 1993 etc.) and also from Silesia (Kempný 1958). However, all specimens from the Czech Republic referred to P. tibialis have been recognized by Dušek \& Láska (1987) and Holinka \& Mazánek (1997) as specimens of the more common similar species $P$. haemorrhous Meigen, 1822; in some cases records were based on female specimens that are hardly separable from the latter common species. So, these authors decided that $P$. tibialis (including $P$. constrictus) is not known to occur in the Czech Republic and replaced this species by P. haemorrhous in all versions of checklists of Syrphidae of the Czech Republic (Dušek \& Láska 1987, Holinka \& Mazánek 1997, Mazánek 2006, 2009). P. constrictus has to be added to the Red list of threatened Syrphidae in the Czech Republic (Mazánek \& Barták, 2006) as an endangered (EN) species, because it is considered a very rare species with severely fragmented distribution, and because of limited extent and degradation of its suitable inland sandy habitats. This species will also be assessed as endangered (EN) species in the whole of Europe (European Red List of hoverflies, in prep.). Interestingly, there is an additional unpublished record from N Moravia: Bystřice nr. Třinec, shores of Olše river, 49³8'08"N, 1842'26"E sweeping, 6.-8.vii.2007, 1ð̄, M. Barták leg. et coll., L. Mazánek det.

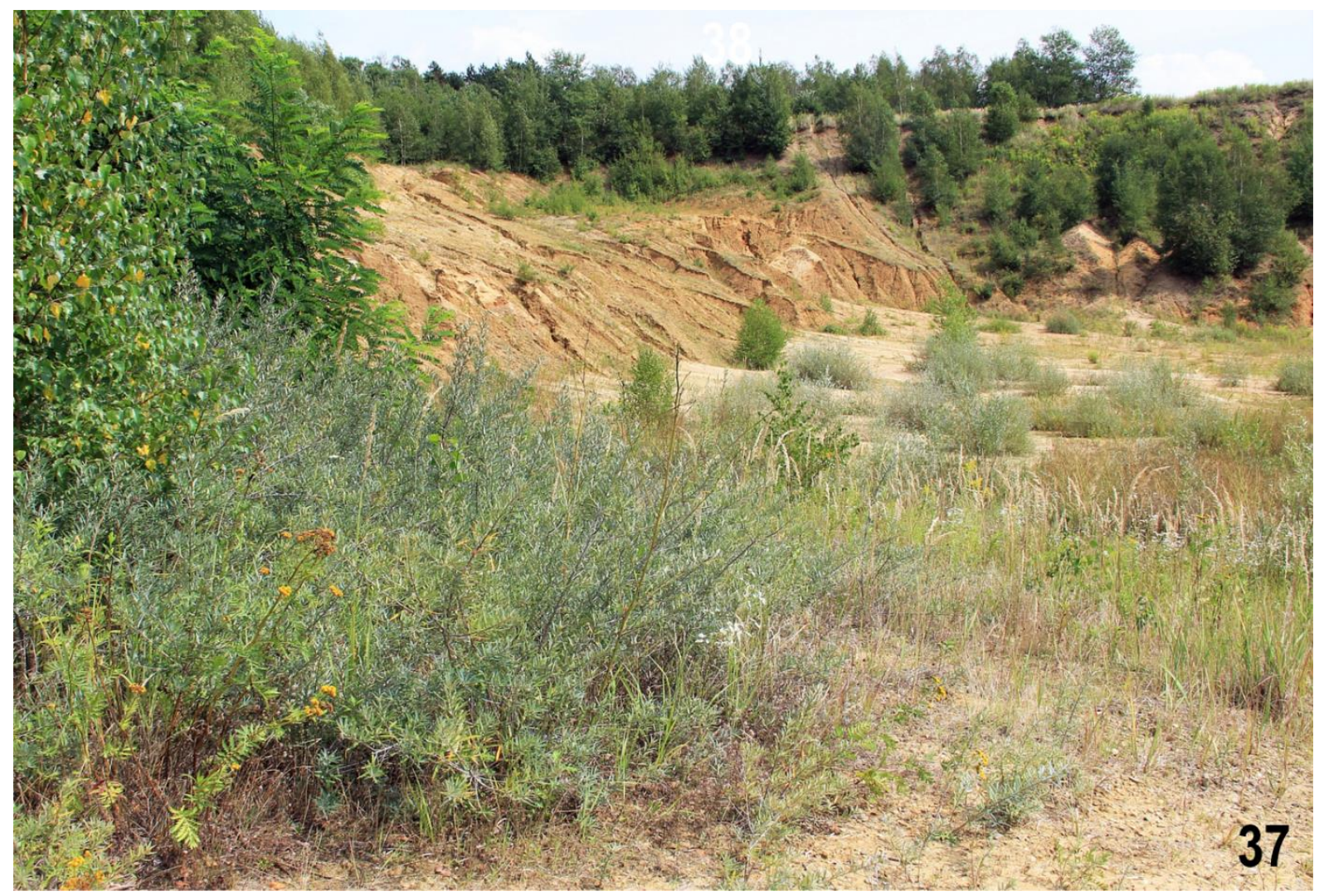

Fig. 37. Habitat of Paragus constrictus Šimić in the Godów sand-pit: southern slopes with sparse flowering vegetation at northern margin, viewed from west (8.viii.2019). Photo J. Roháček.

\section{Pelecocera (Chamaesyrphus) scaevoides (Fallén, 1817) - psammoneutral}

Material examined: CZECH REPUBLIC: N Moravia: Závada 2 km S, sand-pit SW part, 4956'09"N, 18¹0'04"E, $270 \mathrm{~m}$, sweeping over sand and sparse vegetation on sand, 24.vi.2015, 19, J. Roháček leg., L. Mazánek det. (SMOC).

Biology. This species is usually found in open coniferous forests with predominant Pinus trees. Adults fly among ground vegetation in woodland and clearings, and have been recorded visiting flowers of Angelica sylvestris, Cerastium sp., Myosotis sp. Sorbus aucuparia and Potentilla erecta. The flight period of this species ranges from June to September. The developmental stages and feeding mode of larvae of any species of this genus are unknown (Speight 2018, Bartsch et al. 2009a). Only a single specimen has been captured on glacial sands during the present study, in the site with highest abundance of P. tricincta (see Fig. 41). 

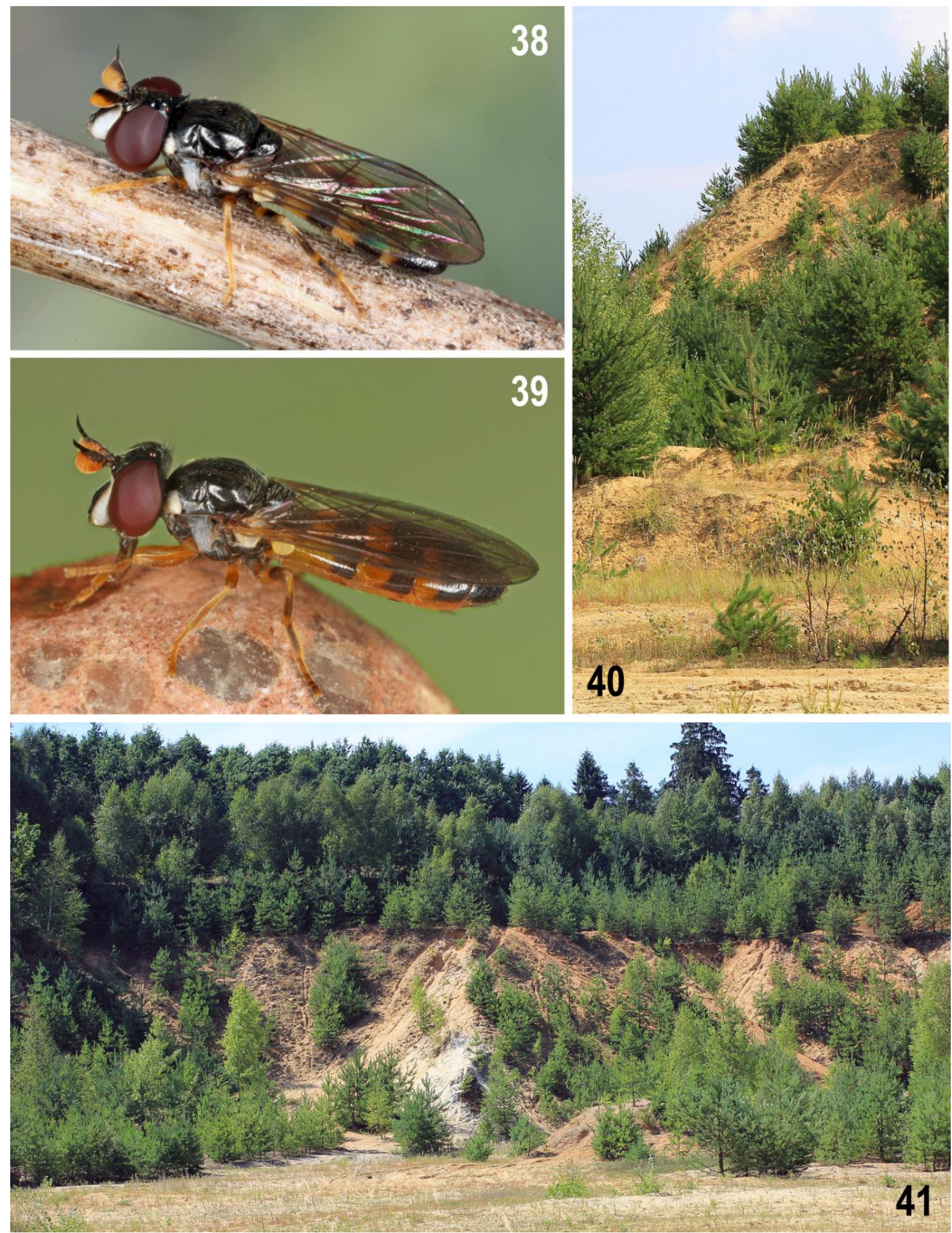

Figs 38-41. Pelecocera tricincta Meigen and its habitat. 38 - male, dorsolaterally, on small twig, body length ca $5.0 \mathrm{~mm} ; 39$ - female, laterally, on small pebble, body length ca $5.6 \mathrm{~mm} ; \mathbf{4 0}$ - habitat of the species, foothill of northern sandy slope with young pines in southwestern part of the Závada sand-pit viewed from northwest (10.ix.2015); 41 - the same site, general view of the habitat (20.viii.2915). Photo J. Roháček. 
Distribution: P. scaevoides is widespread and locally common in Scandinavia (Bartsch et al. 2009a), but in other parts of the Europe it is rather rare and local. It is known from Great Britain (Scottish Highlands), Netherlands (Bot \& de Meutter 2019), France (Aude, Hautes Alpes), Germany, Poland, Czech Republic, Switzerland, Liechtenstein, Italy, North European Russia (Karelia) and the Caucasus Mts (Bartsch et al. 2009a, Speight 2018). In Belgium, the species is known from a single unconfirmed record from the very south (Bot \& de Meutter 2019). Recently it has been recorded also from Ukraine (G. Popov, personal communication, 2019). In the Czech Republic this species is known from Bohemia (Dušek \& Láska 1987) and southern Moravia (Gregor 1978, Mazánek et al. 2006). First record from Silesia.

Comments: Because of its poorly known biology and due to the lack of data on habitat preference (see above) the species is tentatively treated here as psammoneutral. It seems, that this species is more frequent on sandy habitats than on other soil types (e.g. Karl 1930 considered it a true dune species), but it is probably primarily associated with all kinds of open habitats, that are overgrown by Pinus trees. The majority of related species are known to prefer sandy habitats (see Mengual et al. 2015, Vujić et al. 2020).

\section{Pelecocera (Pelecocera) tricincta Meigen, 1822 - psammophilous}

(Figs 38, 39)

Material examined: CZECH REPUBLIC: N Moravia: Bohušov 0.7 km S, 50¹4'14"N, 1742'57"E, $250 \mathrm{~m}$, abandoned sand-pit, sweeping over sand and vegetation on sand, 11.ix.2019, $10^{\uparrow}$; Závada $1.6 \mathrm{~km} \mathrm{~S}$, sand-pit NW part, 49 $56^{\prime} 25^{\prime \prime} \mathrm{N}, 18^{\circ} 09^{\prime} 56^{\prime \prime E}, 265 \mathrm{~m}$, sweeping over sand and sparse vegetation on sand, 12.v.2015, 1 \%; Závada $1.8 \mathrm{~km}$ SE, sand-pit SE part, 49 $56^{\prime} 19^{\prime \prime} \mathrm{N}, 18^{\circ} 10^{\prime} 28^{\prime \prime} \mathrm{E}, 260 \mathrm{~m}$, sweeping over sand and sparse vegetation on sand, 25.v.2016, $20^{\wedge}$ 1 ; Závada $2 \mathrm{~km} \mathrm{~S}$, sand-pit SW part, 49 56 $06^{\prime \prime} \mathrm{N}, 18^{\circ} 10^{\prime} 04^{\prime \prime E}, 270 \mathrm{~m}$, sweeping over sand and

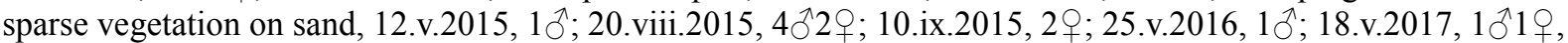
all J. Roháček leg., L. Mazánek det. (SMOC).

Biology: P. tricincta occurs in dry and sparse pine forests, open heathlands and dune areas overgrown with young Pinus trees, but it is also known from open wetlands such as marshes and from open areas within Castanea forests (Speight 2018, Bartsch et. al. 2009). Adults fly usually close to the ground in forest clearings and along paths, preferably adjacent to heaths, or in low wetland vegetation. They visit flowers of various Asteraceae, Geranium sp., Calluna vulgaris, Potentilla erecta, Ranunculus, Narthecium, Sedum acre, Conopodium majus, Cistus salviifolius and Teucrium (see Kehlmaier 2002). The flight period of adults lasts from V to IX (or early X) in southern Europe, from second half of May to the end of August in northern Europe (Speight 2018, Bartsch et al. 2009a, Kehlmaier 2002). The larvae of this genus, as well as their microhabitat requirements and feeding mode are still unknown. Karl (1930) considered it a true dune species on coasts of the North and Baltic Seas and also Ardö (1957) recorded it from this habitat. This seems not the case in Great Britain (Howe 2010) and/or Norway (Nielsen at al. 2019). The presence of pines may be crucial for the occurrence of $P$. tricincta on sand because also in the area under study it was only recorded in sand-pits with (young) pines (cf. Figs 40, 41).

Distribution: This species is known from Fennoscandia south to the Iberian Peninsula, from Britain (southern England) eastwards through much of Europe (including Italy and northern parts of the Balkans) into European parts of Russia (Karelia, Lipetsk Region, Voronezh Region, the Caucasus Mts) and to Asian Russia (Siberia to CisBaikal) (Speight 2018, A. V. Barkalov pers. comm.). In the Czech Republic the species is known from Bohemia (Vimmer 1913, Dušek \& Láska 1987) and southern Moravia (Gregor 1978, Mazánek et al. 2006). First records from Silesia.

Comments: $P$. tricincta is considered here a psammophilous species because this and other congeners are most frequently found in or near sand dunes and in coniferous forest with open ground, such as dry Pinus forest with heathland (Mengual et al. 2015). Although P. tricincta is known across virtually all of Europe, it remains a rare species in most parts of the subcontinent (Bartsch et al. 2009a). Large and stable populations have usually been reported from coastal habitats, e.g. from Monte Ulía that is part of the eastern end of the tertiary coastal chain and consists mainly of Eocene sandstone formations in northern Spain (Kehlmaier 2002). In the Czech Republic, $P$. tricincta is very rare, with small fragmented populations, probably because of the limited extent of suitable inland habitats. Nevertheless, information on larval biology is necessary to better understand habitat requirements of this species. Moreover, this information will also probably enable the high variability in body size of adults to be understood (Kehlmaier 2002). P. tricincta is listed as a vulnerable (VU) species in the Red List of threatened Syrphidae in the Czech Republic (Mazánek \& Barták 2006).

\section{Discussion and conclusions}

The deposits of glacial sand in the Czech Silesia (NE Czech Republic) were formed during Pleistocene glaciations. In localities under study they originate from the Elsterian (ca 400000 ya) and Saalian glaciations (ca 160000 ya), cf. Růžičková et al. (2001), Růžička (2004), and Nývlt et al. (2011). Both glaciofluvial (in Jesenicko and Osoblažsko regions) and glacio- 
lacustrine (largely in Hlučínsko and Karvinsko regions) sand and gravel sediments occur in the area (Růžičková et al. 2001). At present, the typical sandy habitats in Silesia are mainly developed in sites with sand exposed due to excavation (active and abandoned sand-pits). The natural outcrops of glacial sand are much rarer in the Czech Silesia and were only found in two small areas of non-cultivated land near the Bělá village (near Chuchelná): a sandhill called "Buben" (see Roháček 2020: Fig. 6) and northern slopes of another sand-hill opposite to the southern margin of a holt at this village (Roháček 2020: Fig. 7). These sand-hills are in fact remains of large sand dunes originally formed on shores of postglacial lakes which evolved from a melted glacier after the Saalian glaciation (Růžičková et al. 2001, Nývlt et al. 2011). Some sand-pits in the Hlučínsko region (e.g. Závada) are also mining sand of the same origin. For the above reasons the glacial sand habitats occur in a few localities and are of very limited extent in the area. In spite of these limitations they seem to represent a distinctive (albeit very insular) ecosystem with a highly specific sand-loving fauna and flora, markedly different from those of the surrounding, largely agricultural, landscape.

The current research of Diptera on glacial sand habitats in the Czech Silesia has markedly contributed to the knowledge of this group in this specific ecosystem. In addition to Acalypterates (Roháček 2015a, 2016a, Roháček et al. 2020) numerous interesting species of other groups of Diptera have also been encountered and some of them (a total of 19 species) belonging to the lower Brachycera are treated in this paper. They represent new additions to the dipterous fauna of the Czech Republic (one of them even to Europe), Moravia or at least the Czech Silesia. The finding of Medetera grunini (Dolichopodidae) is most significant because this species has previously only been recorded from Kazakhstan in Central Asia (Negrobov 1991). Also records of Rhamphomyia murina (Empididae) and Drapetis monsmargila (Hybotidae) are important because they represent new southernmost distribution range limits of these species.

Results of this study revealed a number of additional sand-loving species forming an important and characteristic component of the dipterous community inhabiting glacial sand deposits in the Czech Silesia. We can add an additional 11 species with close affinity to sandy habitats to the current species list (Roháček \& Ševčík 2013, Roháček 2015a,b, 2016a,b, 2020, Roháček et al. 2020). Two of them are psammobiont, viz. Dialineura anilis (Therevidae) and Schistostoma truncatum (Dolichopodidae), 6 psammophilous, viz. Exhyalanthrax afer (Bombyliidae), Cliorismia rustica (Therevidae), Cryptophlebs kerteszi, Melanostolus melancholicus (both Dolichopodidae), Paragus constrictus Šimić, 1986, Pelecocera tricincta Meigen, 1822 (both Syrphidae) and additionally 3 probably psammophilous, viz. Medetera annulitarsus, M. grunini and Sciapus basilicus (all Dolichopodidae). All of them seem to be associated with bare sand or with sandy ground with sparse spontaneous vegetation but some of the Dolichopodidae mainly occur on more humid sand (Cryptophlebs kerteszi, Sciapus basilicus) or on sandy riparian habitats (Melanostolus melancholicus in the Dolní Lutyně sandpit).

Also thermophilous and/or xerophilous species are an interesting component of the fly fauna of glacial sand deposits (cf. also Roháček 2015b, 2016a, Roháček et al. 2020) because most of them are of southern origin. Empis filata (Empididae), Drapetis monsmargila (Hybotidae) and Medetera grunini (Dolichopodidae) seem to belong to this group.

The results presented above confirm again that glacial sand deposits (and sand-pits in particular) in the Czech Silesia are valuable (albeit insular) refugia (cf. also Roháček 2020) for survival of sand-loving Diptera. Better knowledge of the fly communities in this extreme and (in Central Europe) fragmentary ecosystem will surely contribute to the understanding of the postglacial evolution of the sand-loving insect fauna in this part of Europe. 
Acknowledgements: We would like to thank Z. Kejval (Domažlice, Czech Republic), J. Starý (Olomouc, Czech Republic), J. Ševčík (Ostrava, Czech Republic) and T. Zatwarnicki (Opole, Poland) for discussion on psammophilous fauna of Diptera, L. Dvořák (Marianské Lázně, Czech Republic) for unpublished faunal data on some Therevidae and L. Ć́hal (Opava, Czech Republic) for kind help with preparation of maps for this article. O. Psotka, the owner of the sand-pit Kolnovice, and H. Rajca (both from Mikulovice, Czech Republic), and also R. Sekanina, the plant manager of the sand-pit Dolní Lutyně (Dětmarovice, Czech Republic) are cordially thanked for enabling field work in these active sand-pits. The kind assistance of L. Jarošová (Opava, Czech Republic) and E. Chválková (Ostrava, Czech Republic) during field work also is much appreciated. We are particularly grateful to P. Chandler (Melksham, England) for valuable suggestions, additions and language corrections of the manuscript. The research and field work of J. R. was realized within the framework of the project NAKI II DG18P02OVV047 Velký historický atlas českého Slezska [Great Historical Atlas of the Czech Silesia] supported by the Ministry of Culture of the Czech Republic.

\section{References}

Andersson H. (1974): Studies on the myrmecophilous fly, Glabellula arctica (Zett.) (Diptera, Bombyliidae). Entomologica scandinavica 5: 29-38.

Ardö P. (1957): Studies in the marine shore dune ecosystem with special reference to the dipterous fauna. Opuscula Entomologica, 14 (suppl.): 1-255.

Bartáková D. \& Barták M. (2004): Dispersal patterns of predatory flies from families Empididae, Hybotidae and Microphoridae (Diptera) in agroecosystems and adjacent areas. Dipterologica Bohemoslovaca 11. - Folia Fac. Sci. Nat. Univ. Masaryk. Brun. Biol. 108: 37-50.

Bartsch H., Binkiewicz E., Klintbjer A., Rådén A. \& Nasibov E. (2009a): Nationalnyckeln till Sveriges flora och fauna. Tvåvingar: Blomflugor: Eristalinae \& Microdontinae. [National key to Swedish flora and fauna. Two-winged flies: hoverflies: Eristalinae \& Microdontinae]. Diptera: Syrphidae: Eristalinae \& Microdontinae. DH53b. Artdatabanken, SLU, Uppsala. 478 pp. (in Swedish).

Bartsch H., Binkiewicz E., Rådén A. \& Nasibov E. (2009b): Nationalnyckeln till Sveriges flora och fauna. Tvåvingar: Blomflugor: Syrphinae. [National key to Swedish flora and fauna. Two-winged flies: hoverflies: Syrphinae]. Diptera: Syrphidae: Syrphinae. DH53a. Artdatabanken, SLU, Uppsala. 406 pp. (in Swedish).

Becker T. (1917-2018): Dipterologische Studien. Dolichopodidae. A. Paläarktische Region. - Nova Acta Academiae Caesareae Leopodinisch-Carolinae Germanicae Naturae Curiosorum 102(2)(1917): 113-361, 103(3)(1918): 203-315, 104(2)(1918): 35-214.

Bellstedt R. \& Stark A. (2006): Langbeinfliegen (Diptera, Dolichopodidae) im Kalkquellmoor "Benninger Ried" bei Memmingen, Bayern. - Lauterbornia 57: 149-152.

Beuk P.L.T. \& Goot V.S. van der (2019): Family Empididae. In: Beuk P.L.T. (ed.): Checklist of the Diptera of the Netherlands, https://diptera-info.nl/news.php?fam=Empididae (date accessed: 21/01/2021).

Bosák J. (1997): Bombyliidae. Faunistic records from the Czech and Slovak Republics: Diptera. In: Rozkošný R. \& Vaňhara J. (eds): Dipterologica bohemoslovaca 8. - Folia Facultatis Scientiarum Naturalium Universitatis Masarykianae Brunensis, Biologia 95: 216-217.

- (1998): Phthiriidae, Bombyliidae. Pp. 147-149. In: Rozkošný R. \& Vaňhara J. (eds): Diptera of the Pálava Biosphere Reserve of UNESCO, I. - Folia Fac. Sci. Nat. Univ. Masaryk. Brunensis, Biologia 99: 147-149.

- (2005): Mythicomyiidae. P. 281. In: Farkač J., Král D. \& Škorpík M. (eds): Červený seznam ohrožených druhů České republiky. Bezobratlí. Red List of threatened species in the Czech Republic. Invertebrates. Agentura ochrany př́rody a krajiny ČR, Praha, 760 pp. (in Czech and English).

Bosák J. \& Barták M. (2000): Mythicomyiidae. In: Barták M. \& Vaňhara J. (eds): Diptera in a Industrially Affected Region (North-Western Bohemia, Bílina and Duchcov Environs), I. - Folia Facultatis Scientiarum Naturalium Universitatis Masarykianae Brunensis, Biologia 104: 147-149.

Bot S. \& Van de Meutter F. (2019): Veldgids Zweefvliegen. 384 soorten, Nederland en België, determinatiesleutels. [Field Guide Hoverflies. 384 species, Netherlands and Belgium, identification keys]. KNNV Uitgeverij, Zeist, 388 pp. (in Dutch).

Brighton P. (2019): The Diptera of Lancashire and Cheshire: Empidoidea, Part I. 32, Wadeson Way, Croft, Warrington WA3 7JS. Version 1.1. 1-47.

Bygebjerg R. (2004): Fund af svirrefluer i Danmark i perioden 2000-2003 (Diptera, Syrphidae). Records of hoverflies from Denmark in the years 2000-2003 (Diptera, Syrphidae). - Entomologiske Meddelelser 72: 81100 (in Danish, with English abstract).

Bystrowski C., Richter V.A., Beuk P.L.T. \& Chvála M. (2013a): Fauna Europaea: Empididae. In: Beuk P.L.T. \& Pape T. (eds): Fauna Europaea: Diptera, Brachycera. Version 2017.06, https://fauna-eu.org (date accessed: 21/01/2021). 
Bystrowski C., Richter V.A., Beuk P.L.T. \& Chvála M. (2013b): Fauna Europaea: Schistostoma. In: Beuk P.L.T. \& Pape T. (eds): Fauna Europaea: Diptera, Brachycera. Version 2017.06, https://fauna-eu.org (date accessed: 21/01/2021).

Ceianu I. (1992): Contribution to the knowledge of superfamily Empidoidea (Diptera) in Romania I. - Travaux du Museum National d'Histoire Naturelle "Grigore Antipa" 32: 17-48.

Čelechovský A., Čelechovský D. \& Čelechovský M. (2021): Dlouhososky Exhyalanthrax afer (Fabricius, 1794) a Thyridanthrax fenestratus (Fallén, 1814) - první nálezy v národním parku Podyjí (Diptera: Bombyliidae). [Bee flies Exhyalanthrax afer (Fabricius, 1794) and Thyridanthrax fenestratus (Fallén, 1814) First records in the Podyjí national park (Diptera: Bombyliidae)] - Thayensia 17(2020): 247-250 (in Czech, with English abstract).

Chandler P.J. (ed.) (1998): Checklists of Insects of the British Isles (New Series). Part 1: Diptera. - Handbooks for the Identification of British Insects 12(1): 1-234.

Chvála M. (1983): The Empidoidea (Diptera) of Fennoscandia and Denmark. II. General Part. The families Hybotidae, Atelestidae and Microphoridae. Fauna Entomologica Scandinavica, Vol. 12, Scandinavian Science Press Ltd., Klampenborg, 279 pp.

- (1987): Revision of Palaearctic Microphoridae (Diptera) 2. Schistostoma Beck. - Acta Entomologica Bohemoslovaca 84: 133-155.

- (1991): Zpráva o inventarizačním výzkumu dvoukřídlého hmyzu (Insecta, Diptera) SPR Radotínské údolí v roce 1991 [Report on inventory study of two-winged flies (Insecta, Diptera] in the Radotínské údolí reserve in 1991]. - Unpublished manuscript, Dep. Správa CHKO Český kras, Karlštejn, 4 pp (in Czech).

- (1994): The Empidoidea (Diptera) of Fennoscandia and Denmark. III. General Part. The families Hybotidae, Atelestidae and Microphoridae. - Fauna Entomologica Scandinavica 29: 1-187.

- (2009): Empididae Latreille, 1804. In: Jedlička L., Kúdela M. \& Stloukalová V. (eds): Checklist of Diptera of the Czech Republic and Slovakia. Electronic version 2, http:/www.edvis.sk/diptera2009/families/ empididae.htm

Chvála M. \& Barták M. (2000): Empididae. In: Barták M. \& Vaňhara J. (ed.): Diptera in an industrially affected region (North-Western Bohemia, Bílina and Duchcov environs) I. - Folia Fac. Sci. Nat. Univ. Masaryk. Brun., Biologia 104: 175-181.

Chvála M. \& Pont A.C. (2015): Revision of the European Empis (s. str.) alpicola-group of species (Diptera: Empididae), with a new synonymy of Rhamphomyia subgenus Aclonempis Collin with the subgenus Empis Linnaeus s. str. - Studia Dipterologica, 21(1)[2014]: 53-68.

Chvála M. \& Vrtišková-Boušková J. (1989): Fauna of the Empididae and Hybotidae (Diptera) of Prague, Czechoslovakia. - Acta Universitatis Carolinae Biologica 31(5-6)(1987): 373-405.

Chvála M. \& Wagner R. (1989): Family Empididae. Pp. 228-336. In: Soós Á. \& Papp L. (eds): Catalogue of Palearctic Diptera, Vol 6, Therevidae - Empididae, Akademiai Kiado, Budapest, 435 pp.

Cole J. H. (1987): Dolichopodidae difficulties. - Empid and Dolichopodid Study Group Newssheet 3: 2-3.

Collin J.E. (1926). Notes on the Empididae (Diptera), with additions and corrections to the British list. - The Entomologist's Monthly Magazine. 62: 213-219.

Crossley R. (2007): Entomological report: Diptera (Tipuloidea and Empidoidea). - Naturalist 132: 69-72.

Czižek K. (1906): Beiträge zu einer Dipterenfauna Mährens. - Zeitschrift des Mährischen Landesmuseums, Brünn 6: 182-234.

Danihelka J., Chrtek J. Jr. \& Kaplan Z. (2012): Checklist of vascular plants of the Czech Republic. Preslia 84: 647-811.

Denninger E. (1950): Zur Synonymie einiger Dolichopodidenarten (Dipt.). - Jahresh. Ver. F. Vaterl. Naturk., Württemberg 102-105(1946-1949): 42-48.

Drake C.M. (2020): Two species of Chrysotus (Diptera, Dolichopodidae) new to the British list. - Dipterists Digest 27: 127-137.

Dušek J. \& Láska P. (1987): Syrphidae. In: Ježek J. (ed.): Enumeratio insectorum bohemoslovakie. Check List of Czechoslovak Insects II (Diptera). - Acta Faunistica Entomologica Musei Nationalis Pragae 18: 151159.

Engel O. (1938-1956): Empididae. In: Lindner E. (ed.): Die Fliegen der palae-arktischen Region, Vol 4, E. Schweizerbart'sche Verlagsbuchhandlung, Stuttgart, 434 pp.

Evenhuis N.L. (2002): Catalog of the Mythicomyiidae of the world (Insecta: Diptera). - Bishop Museum Bulletin in Entomology 10: 1-85.

Evenhuis N.L. \& Bosák J. (1997): New records of Glabellula arctica (Zetterstedt, 1838) (Diptera, Mythicomyiidae) from Czech Republic and Slovak Republic. - Časopis Slezského Muzea Opava (A) 46: 95-96.

Evenhuis N.L. \& Greathead D.J. (1999): World Catalog of Bee Flies (Diptera: Bombyliidae). Backhuys Publisher, Leiten, Netherlands. 756 pp.

- (2003): World Catalog of Bee Flies (Dipera: Bombyliidae): Corrigenda and Addenda. - Zootaxa, 300: 1-64. 
Falk S.J. \& Crossley R. (2005): A review of the scarce and threatened flies of Great Britain. Part 3: Empidoidea. Species Status 3: 1-134. Version 1.4. Joint Nature Conservation Committee, Peterborough.

Gatt P. (2014): Order Diptera, family Dolichopodidae, A new species of the subfamily Microphorinae. Pp. 718724. In: Harten A. van (ed.): Arthropod fauna of the United Arab Emirates, Vol. 5, Department of the President's Affairs, United Arab Emirates, 744 pp.

Gibbs D. (1988): Some Diptera from Buckinghamshire Wetlands. - Dipterists Digest 1: 36-37.

Goot V.S. van der. (1989): De dansvliegen van het geslacht Empis in Nederland (Diptera: Empididae). [The dance flies of the genus Empis in the Netherlands (Diptera: Empididae)] - Entomologische Berichten, Amsterdam 49: 173-184 (in Dutch).

Greathead D.J. (2013a): Fauna Europaea: Bombyliidae. In: Beuk P. \& Pape T. (eds): Fauna Europaea: Diptera, Brachycera. Fauna Europaea version 2017.06, https://fauna-eu.org (accessed 2 December 2020).

- (2013b): Fauna Europaea: Mythicomyiidae. In: Beuk P. \& Pape T. (eds): Fauna Europaea: Diptera, Brachycera. Fauna Europaea version 2017.06, https://fauna-eu.org (accessed 3 December 2020).

Greathead D.J., Barták M. \& Kubík Š. 2005: Mythicomyiidae. Pp. 136-137. In: Barták M. \& Kubík Š. (eds): Diptera of Podyjí National Park. Česká zemědělská univerzita v Praze, 432 pp.

Greathead D.J. \& Grandcolas P. (1995): A new host association for the Bombyliidae (Diptera): an Exhyalanthrax sp. reared from cockroach oothecae, Heterogamisca chopardi (Dictyoptera: Polyphagidae) in Saudi Arabia. - The Entomologist 114(2): 91-98.

Gregor T. (1978): Výsledek průzkumu pestřenek v zátopové oblasti řeky Jevišovky na Moravě (Diptera, Syrphidae). [Result of study of hoverflies in flood area of the Jevišovka river in Moravia]. - Zprávy Československé Společnosti Entomologické při ČSAV, Praha 14: 131-139 (in Czech, with German summary).

Grichanov I.Y. \& Negrobov O.P. (2014): Palaearctic species of the genus Sciapus Zeller (Diptera: Dolichopodidae). - Plant Protection News, Supplement 13: 1-85.

Grootaert P., Beuk P. \& Shamshev I. (2020): A new species of Drapetis Meigen from calcareous grassland in southern Netherlands (Diptera, Hybotidae, Tachydromiinae). - Belgian Journal of Entomology 97: 1-11.

Grootaert P., Dekoninck W. \& Bonte D. (2001): Therevidae (Diptera) in the East-Flemish inland dunes, pioneers on sandy soils? - Bulletin de la Société Royale Belge d'Entomologie / Koninklijke Belgische Vereniging Voor Entomologie 137: 32-35.

Grootaert P., Dekoninck W. \& Desender K. (2005): Succession of dance fly fauna (Diptera: Empidoidea: Empididae, Hybotidae, Microphoridae) in ancient forests and afforested former agricultural land: a case-study in the "Voerstreek" (Belgium, Flanders): faunistics and new species for the Belgian fauna. - Bulletin de l'Institut royal des Sciences naturelles de Belgique. Entomologie 75: 305-319.

Haarto A. (2014): Identification of the Finnish species of Paragus Latreille, 1804 subgenus Pandasyopthalmus Stuckenberg, 1954 (Diptera, Syrphidae). - Sahlbergia 20: 2-5.

Haarto A. \& Winqvist K. 2006. Finnish flies of the family Therevidae. - Entomologica Fennica 17: 46-55.

Heřman P. \& Chvála M. (2014): On the occurrence of the dance flies (Diptera: Empididae and Hybotidae) in the Český kras/Bohemian Karst and its close environs. - Bohemia centralis, Praha 32: 357-375.

Hewitt S. \& Parker J. (2008): Distribution of the stiletto-fly Cliorismia rustica on Cheshire rivers. Report for Environment Agency, Buglige, iv + 35 pp. https://cdn.buglife.org.uk/2019/07/cheshire-2007-08-finalreport-web.pdf

Holinka J. \& Mazánek L. (1997): Syrphidae. Pp. 60-66. In: Chvála M. (ed.): Check list of Diptera (Insecta) of the Czech and Slovak Republics. Karolinum - Charles University Press, Prague, 130 pp.

Holston K. C. (2013): Fauna Europaea: Therevidae. In: Beuk P. \& Pape T. (eds): Fauna Europaea: Diptera, Brachycera. Fauna Europaea version 2017.06, https://fauna-eu.org (accessed 3 December 2020).

Howe M. A. (2010): Chapter 4. The habitats of Diptera. Coastal sand dunes. Pp. 269-276. In Chandler P. (ed.): A dipterist's handbook (2nd Edition). The Amateur Entomologist Vol. 15, The Amateur Entomologist's Society, Brentwood, Essex, 525 pp.

Jedlička L., Kúdela M. \& Stloukalová V. (eds) (2009): Checklist of Diptera of the Czech Republic and Slovakia. Electronic version 2. http://www.edvis.sk/diptera2009/mapCZSK.htm

Kahanpää J. (2014): Checklist of the Empidoidea of Finland (Insecta, Diptera). - ZooKeys 441: 183-207.

Karl O. (1930): XI. e2. Thalossobionte [sic!] und thalassophile Diptera Brachycera. In: Grimpe G. \& Wagler E. (eds): Die Tierwelt der Nord- und Ostsee 14(11, e2), Akademische Verlagsgesellschaft, Leipzig, pp. 33-84.

Karlsson D., Hartop E., Forshage M., Jaschhof M. \& Ronquist F. (2020): The Swedish Malaise Trap Project: A 15 Year Retrospective on a Countrywide Insect Inventory. - Biodiversity Data Journal 8, e47255: 1-35. doi: 10.3897/BDJ.8.e47255.

Kehlmaier C. (2002): Hoverflies (Diptera, Syrphidae) from northern Spain, with notes on Pelecocera tricincta Meigen, 1822. - Volucella, Stuttgart 6: 139-153.

Kempný L. (1958): Tři zajímavé pestřenky (Diptera, Syrphidae) slezské oblasti. [Three interesting species of hoverflies (Diptera, Syrphidae) from the region of Silesia]. - Př́rodovědecký Sborník Ostravského Kraje 19: 234-243 (in Czech, with Russian and German summary). 
Kheil P. (2003): Habitat and microhabitat preferences of mountain Therevidae (Diptera), and ecological outline of Czech Therevidae. Unpublished Bachelor Thesis, University of South Bohemia, Faculty of Biological Sciences, České Budějovice, 23 pp + Appendix (7 pp.).

Kowarz F. (1885): Beiträge zu einem Verzeichnisse der Dipteren Böhmens VI. - Wiener Entomologische Zeitung 4: 105-108, 133-136, 167-168, 201-208, 241-244.

Krogerus R. (1932): Über die Ökologie and Verbreitung der Arthropoden det Triebsandgebiete an den Küsten Finnlands. - Acta Zoologica Fennica 12: 1-308.

- (1960): Ökologische Studien über nordische Moorarthropoden. - Commentationes Biologicae 21(3): 1-238.

Loew H. (1864): Ueber die schlesischen Arten der Gattungen Tachypeza Meig. (Tachypeza, Tachista, Dysaletria) und Microphorus Macq. (Trichina und Microphorus). - Zeitschrift für Entomologie Breslau 14 (1860): 1-50.

Máca J. (2006): Notes to the termophilous arthropods in southern Bohemia. - Acta Musei Bohemiae meridionalis in České Budějovice, Scientiae naturales 46: 189-194.

Mazánek L. (2006): Syrphidae Latreille 1802. In: Jedlička L., Stloukalová V. \& Kúdela M. (eds): Checklist of Diptera of the Czech Republic and Slovakia. Electronic version 1. http://zoology.fns.uniba.sk/ diptera + CD-ROM: ISBN 80-969629-0-6.

- (2009): Syrphidae Latreille 1802. In: Jedlička L., Kúdela M. \& Stloukalová V. (eds): Checklist of Diptera of the Czech Republic and Slovakia. Electronic version 2. http://www.edvis.sk/diptera2009/families/ syrphidae.htm

Mazánek L. \& Barták M. (2006): Syrphidae (pestřenkovití). Pp. 300-303. In: Farkač J., Král D. \& Škorpík M. (eds): Červený seznam ohrožených druhů České republiky. Bezobratlí. Red list of threatened species in the Czech Republic. Invertebrates. Agentura ochrany př́rody a krajiny České republiky, Praha, 758 pp. (in Czech and English).

Mazánek L., Vujić A., Gregor T., Barták M. \& Kubík Š. (2006): Syrphidae. Pp. 197-229. In: Barták M. \& Kubík Šs. (eds): Diptera of Podyjí National Park and its Environs. Česká zemědělská univerzita v Praze, Praha, 432 pp.

Mengual X., Kazerani F., Talebi A. A. \& Gilasian E. (2015): A revision of the genus Pelecocera Meigen with the description of the male of Pelecocera persiana Kuznetzov from Iran (Diptera: Syrphidae). Zootaxa 3947(1): 99-108.

Merle P. du (1975). Les hôtes et les stades pré-imaginaux des Diptères Bombyliidae: Revue bibliographique annotée. Organisation internationale de lutte biologique. - Bulletin Section Régionale Ouest Palaearctique (SROP) 4: 1-289.

Merz B. (1998): The Atelestidae and Microphoridae (Diptera, Empidoidea) of Switzerland. - Bulletin de la Société Entomologique Suisse 71(1-2): 27-31.

Meuffels H.J.G. \& Grootaert P. (1990): The identity of Sciapus contristans (Wiedemann, 1817) (Diptera: Dolichopodidae), and a revision of the species group of its relatives. - Bulletin de l'Institut royal des Sciences naturelles de Belgique, Entomologie 60: 161-178.

Michelsen V. \& Grootaert P. (2019): Drapetis abrollensis sp. nov. from Skåne (Sweden) with a key to males of the NW European species of Drapetis Meigen (Diptera: Hybotidae). - Zootaxa 4624(3): 431-441.

Mielczarek L.E. (2018): Nowe dane o muchówkach z rodziny Mythicomyiidae i Bombyliidae (Usiinae) dla Polski, Bułgarii, Ukrainy i Iranu. New records of Mythicomyiidae and Bombyliidae (Usiinae) for Poland, Bulgaria, Ukraine and Iran. - Dipteron, Wrocław 34: 68-70 (in Polish, with English abstract and summary).

Motyčková V. (2012): Dlouhososky podčeledí Anthracinae a Exoprosopinae v České republice a na Slovensku (Diptera: Bombyliidae). [Bee flies of the subfamilies Anthracinae and Exoprosopinae in the Czech Republic and Slovakia (Diptera: Bombyliidae)]. Nepublikovaná bakalářská práce. Př́rodovědecká fakulta, Univerzita Palackého, Olomouc, 56+12 pp. (in Czech, with English abstract). https://theses.cz/id/sqdf6u/Veronika Motyckova_Dlouhososky.pdf

Naglis S. \& Negrobov O.P. (2014): New species and new records of Medetera (Diptera, Dolichopodidae) from Switzerland. - Mitteilungen der Schweizerischen Entomologischen Gesellschaft 87: 229-245.

Negrobov O.P. (1991): Family Dolichopodidae. Pp. 11-139. In: Soós Á. \& Papp L. (eds): Catalogue of Palaearctic Diptera. Vol. 7. Dolichopodidae - Platypezidae, Akadémiai Kiadó, Budapest, 291 pp.

Negrobov O.P. \& Chandler P.J. (2006): The status of Chrysotus angulicornis Kowarz (Diptera, Dolichopodidae) and its deletion from the British list. - Dipterists Digest 13: 103-109 (2007).

Negrobov O.P. \& Naglis S. (2016): Palaearctic species of the genus Medetera (Diptera: Dolichopodidae). Zoosystematica Rossica 25(2): 333-379.

Nielsen B.O., Nielsen L.B. \& Toft S. (2016): Epigaeic Diptera Nematocera from the coastal sand dunes of National Park Thy, Denmark. Entomologiske Meddelelser, Kobenhavn 84: 1-34

Nielsen B.O., Nielsen L.B. \& Toft S. (2019): Epigaeic Diptera Brachycera from the coastal sand dunes of National Park Thy, Denmark. Entomologiske Meddelelser, Kobenhavn 87: 19-40.

Niesiolowski S. (2006): Morphology, biology, phenology and occurrence of the genus Empis Linnaeus (Empididae, Diptera) in Poland. - Fragmenta Faunistica 49(1): 1-39. 
Nývlt D., Engel Z. \& Tyráček J. (2011): Chapter 4. Pleistocene glaciation in Czechia. Pp. 37-45. In: Ehlers J., Gibbart P. L. \& Hughes P. D. (eds): Quaternary Glaciations - extent and chronology: a closer look. Elsevier, Amsterdam, 1108 pp.

Olejníček J. (1983): Faunistic Records from Czechoslovakia. Diptera. Dolichopodidae. - Acta Entomologica Bohemoslovaca 80(5): 399.

- (1997): Dolichopodidae. Pp. 54-57. In: Chvála M. (ed): Check List of Diptera (Insecta) of the Czech and Slovak Republics. Karolinum, Charles University Press, Prague, 130 pp.

Olejníček J. \& Kozánek M. (1989): Faunistic records from Czechoslovakia - Diptera. - Acta Entomologica Bohemoslovaca 86(4): 314-315.

Palaczyk A. (1991): Empididae. Pp. 142-147. In: Razowski J. (ed.): Checklist of animals of Poland, vol.II, part XXXII/25-29 Insecta: Trichoptera - Siphonaptera, PWN, Wrocław, 342 pp. [In Polish with English comments].

Parent O. (1938): Diptères Dolichopodidae. Faune de France, Vol. 35, Paul Lechevalier et fils, Paris, 720 pp.

Pârvu C. (1992): A synthesis on the distribution of Empididae (Diptera) in Romania with the description of a new species of Hilara Meigen, 1822. - Travaux du Museum National d'Histoire Naturelle "Grigore Antipa" 32: $95-120$.

- (2002): Empididae (Diptera) from Mara basin; additional data from Maramures depression, Romania. - Travaux du Museum National d'Histoire Naturelle "Grigore Antipa" 44: 277-291.

Pârvu C. \& Popescu-Mirceni R. (2007): Genus Schistostoma Becker, 1902 (Diptera: Microphoridae) of Tunisia. Faunistic, morphological and teratological data. [Results of „Punia” 2006 Expedition]. - Travaux du Muséum National d'Histoire Naturelle "Grigore Antipa" 5: 437-446.

Persson M., Pollet M., Struwe I. \& Hedström L. (2019): A revised checklist and time window based province catalogue of the long-legged flies (Diptera: Dolichopodidae) of Sweden, with six new synonymies in Dolichopus Latreille, 1796. - Entomologisk Tidskrift 140(1): 27-57.

Pollet M. (2011): Fauna Europaea: Dolichopodidae. In: Pape T. \& Beuk P. (eds): Fauna Europaea: Diptera, Brachycera. Fauna Europaea version 2.4, http://www.faunaeur.org (accessed on February 1, 2021) .

Pollet M., Germann C. \& Bernasconi M.V. (2011): Phylogenetic analyses using molecular markers reveal ecological lineages in Medetera (Diptera: Dolichopodidae). - Canadian Entomologist 143: 662-673.

Pollet M. \& Grootaert P. (1987): Ecological data on Dolichopodidae (Diptera) from a woodland ecosystem. I. Colour preference, detailed distribution and comparison between different sampling techniques. - Bulletin de l'Institut royal des Sciences naturelles de Belgique, Entomologie 57: 173-186.

Pollet M. \& Ivković M. (2018): Dolichopodidae of riverbeds and springs in Croatia with an updated checklist of Croatia (Diptera). - Zootaxa 4455(3): 401-428.

Pollet M. \& Olejníček J. (2006): Dolichopodidae Latreille, 1809. In: Jedlička L., Stloukalová V., \& Kúdela M. (eds): Checklist of Diptera of the Czech Republic and Slovakia. Electronic version 1. http://zoology.fns.uniba.sk/diptera2006 + CD-ROM, ISBN 80-969629-0-6.

Pollet M. \& Suvák M. (2009): Dolichopodidae Latreille, 1809. In: Jedlička L., Kúdela M. \& Stloukalová V. (eds): Checklist of Diptera of the Czech Republic and Slovakia. Electronic version 2. http://www.edvis.sk/diptera2009/families/dolichopodidae.htm

Ronquist F., Forshage M., Häggqvist S., Karlsson D., Hovmöller R., Bergsten J., Holston K., Britton T., Abenius J., Andersson B., Neerup Buhl P., Coulianos C.-C., Fjellberg A., Gertsson C.-A., Hellqvist S., Jaschhof M., Kjærandsen J., Klopfstein S., Kobro S., Liston A., Meier R., Pollet M., Riedel M., Roháček J., Schuppenhauer M., Stigenberg J., Struwe I., Taeger A., Ulefors S.-O., Varga O., Withers P. \& Gärdenfors U. (2020) Completing Linnaeus's inventory of the Swedish insect fauna: Only 5,000 species left? - Plos One 15(3): e228561: 1-30. doi: 10.1371/journal.pone.0228561.

Roháček J. (2015a): Tetanops myopina Fallén, 1820, a psammophilous species of Otitinae (Diptera: Ulidiidae) found in a sandpit in the northeastern part of the Czech Republic. - Acta Musei Silesiae, Scientiae Naturales 64: $1-10$.

- (2015b): Psammophilous flies (Diptera) on glacial sand deposits in Silesia (Czech Republic). P. 33. In: Hamerlík L., Dobríková D. \& Stoklasa J. (eds): The 8th Central European Dipterological Conference: conference abstracts (Kežmarské Žl’aby, 28.-30. September 2015). Belianum, Banská Bystrica, 79 pp.

- (2016a): Acalyptrate flies (Diptera) on glacial sand deposits in the Hlučínsko region (NE Czech Republic): most interesting records. - Acta Musei Silesiae, Scientiae Naturales 65: 33-46.

- (2016b): Čelnice Tetanops myopina - moucha z doby ledové ve Slezsku [Tetanops myopina - a fly from Ice Age in Silesia]. - Naše př́roda 2016(4): 38-41 (in Czech).

- (2020): Sand-pits as refugia of flies (Diptera) associated with glacial sands in Silesia (Czech Republic) preliminary results. Pp. 160-187. In: Jarošová L. \& Tyranová J. (eds): Krajina a lidé [Landscape and people]. Recenzovaný sborník z mezinárodního workshopu. Konaný dne 20. 10. 2020 v Opavě, SZM Opava, 244 pp. Available at http://atlas-slezska.cz/wokrkshop/02_krajina/02_Krajina_a_lide_sbornik.pdf 
Roháček J., Černý M., Ebejer M.J. \& Kubík Š. (2020): New and interesting records of Diptera on glacial sand deposits in Silesia (NE Czech Republic). Part 1 - Acalyptratae. - Acta Musei Silesiae Scientiae Naturales 69(1): 1-19.

Roháček J. \& Ševčík J. (2013): Dvoukřídlí (Diptera). Pp. 263-283. In: Roháček J., Ševčík J. \& Vlk P. (eds): Př́roda Slezska [Nature of Silesia]. Slezské zemské muzeum, Opava, 480 pp. (in Czech).

Roháček J., Ševčík J. \& V1k P. (eds) (2013): Př́roda Slezska [Nature of Silesia]. Slezské zemské muzeum, Opava, 480 pp. (in Czech, with English abstract \& summary).

Rozkošný R. \& Vaňhara J. (1993): Diptera (Brachycera) of a forest steppe near Brno (Hády hill). Acta Scientiarum Naturalium Academiae Scientiarum Bohemoslovacae Brno 27(2-3): 1-76.

- (1997): Dvoukřídlí (Diptera. Brachycera) Mohelenské hadcové stepi a přilehlého údolí řeky Jihlavy. Diptera Brachycera of the Mohelno serpentine steppe and adjoining Jihlava River valley. - Časopis Západomoravského Muzea Třebíč 28: 31-55 (in Czech with English summary).

Růžička M. (2004): The Pleistocene glaciation of Czechia. Pp. 27-34. In: Ehlers J. \& Gibbard P. L. (eds): Quaternary Glaciations - Extent and Chronology. Part I: Europe. Developments in Quaternary Science. Vol. 2. Elsevier B. V., Amsterdam, 475 pp.

Růžičková E., Růžička M., Zeman A. \& Kadlec J. (2009): Quaternary clastic sediments of the Czech Republic. Textures and structures of the main genetic type. Český geologický ústav, Praha, $68+92$ pp.

Shamshev I. V. (1991): A new species of the genus Schistostoma (Diptera, Empidoidea, Microphoridae) from Mongolia. - Zoologicheskiy Zhurnal 10: 149-151 (in Russian; English translation in Entomological Review 1992, 71(1): 170-172).

- (1993): A review of species of the genus Schistostoma Becker (Diptera, Microphoridae) of the fauna of the Ukraine, Transcaucasia and Middle Asia. - Entomologicheskoe Obozrenie 72(3): 684-697 (in Russian; English translation in Entomological Review 1994, 73(4): 73-87).

- (1999): New records of empidoids (Diptera, Empidoidea) from eastern Europe. - International Journal of Dipterological Research 10: 51-52.

Shamshev I.V. \& Sinclair B.J. (2006): The genus Schistostoma Becker from southern Africa, with an evaluation of its generic status (Diptera: Dolichopodidae s. 1.: Microphorinae). - African Invertebrates 47: 335346.

Sinclair B.J. \& Cumming J.M. (2006): The morphology, higher-level phylogeny and classification of the Empidoidea (Diptera). - Zootaxa 1180: 1-172.

Speight M.C.D. (2018): Species accounts of European Syrphidae, 2018. Syrph the Net, the database of European Syrphidae (Diptera), Vol. 103, Syrph the Net publications, Dublin, 302 pp.

Speight M.C.D. \& Chandler P.J. (1995): Paragus constrictus, Pteromicra pectorosa and Stegana similis: insects new to Ireland and Stegana coleoptrata, presence in Ireland confirmed (Diptera). - Irish Naturalists' Journal 25: 28-32.

Speight M.C.D. \& Meuffels H.J.G. (1989): Campsicnemus compeditus, Melanostolus melancholicus, Syntormon setosus and Systenus pallidus (Diptera: Dolichopodidae), insects new to Ireland. - Irish Naturalists' Journal 23: 92-97.

Spitzer K. (1987): Therevidae. P. 117. In: Ježek J. (ed.): Enumeratio Insectorum Bohemoslovakiae. Check list of Czechoslovakia insects II (Diptera). - Acta Faunistica Entomologica Musei Nationalis Pragae 18: 1-341.

- (1997): Therevidae. P. 46. In: Chvála M. (ed.): Check list of Diptera (Insecta) of the Czech and Slovak Republics. Karolinum - Charles University Press. Prague, 130 pp.

- (1998): Therevidae. In: Rozkošný R. \& Vaňhara J. (eds): Diptera of the Pálava Biosphere Reserve of UNESCO. - Folia Facultatis Scientiarum Naturalium Universitatis Masarykianae Brunensis, Biologia 99: 151153.

Stubbs A.E. \& Drake M. (2014): British Soldierflies and their allies. Second Edition. British Entomological and Natural History Society. Reading, Berkshire, 528 pp.

Tomaj V. (1977): Československé druhy čeledi Bombyliidae (Diptera). [Czechoslovak species of the family Bombyliidae (Diptera)]. Unpublished diploma thesis. Př́rodovědecká fakulta, Univerzita J. E. Purkyně, Brno, 129 pp. (in Czech).

Torp E. (1994): Danmarks Svirrefluer (Diptera: Syrphidae) [Denmark's hoverflies (Diptera: Syrphidae)]. Danmarks Dyreliv [Denmark's Wildlife], Vol. 6. Apollo books, Stenstrup, 490 pp. (in Danish, with English abstract).

Vimmer A. (1913): Seznam českého hmyzu dvoukř́ídlého. (Catalogus Dipterorum) [Checklist of the Czech twowinged insects (Catalogus Dipterorum)]. Entomologické př́ručky VIII. Česká společnost entomologická, Praha, iii + 99 pp. (in Czech).

Vujić A., Speight M., Courcy Williams M. de, Rojo S., Ståhls G., Radenković S., Likov L., Miličić M., Pérez-Bañón C., Falk S. \& Petanidou T. (2020). Atlas of the hoverflies of Greece: (Diptera: Syrphidae). Brill, Leiden, Boston, 410 pp. 
Weele R. van der, Hrivniak L', Kappert J., Manko P., Shamshev I.V \& Oboňa J. (2017): Brachystomatidae, Empididae and Hybotidae (Diptera) of Uzh River Basin, with additions to checklists of Ukraine. - Annales de la Société entomologique de France 53(2): 92-98.

Weele R. van der, Hrivniak L., Manko P. \& Oboňa J. (2016): Contribution to the knowledge of flies from the families Empididae and Hybotidae (Diptera) from selected sites of community importance in the area of the Pieniny Mts (Slovakia). - Acta Musei Silesiae Scientiae Naturales 65: 223-226.

Withers P., Claude J. \& Gens H. (2017): Glabellula arctica (Zetterstedt), a species and family added to the French Fauna (Diptera, Mythicomyiidae). - Dipterists Digest 24: 207-209.

Yang D., Zhu Y., Wang M. \& Zhang L. (2006): World Catalog of Dolichopodidae (Insecta: Diptera). China Agricultural University Press, Beijing, 704 pp. + plates I-XLIV.

\section{Nové a zajímavé nálezy dvoukřídlých (Diptera) na ložiskách glaciálních písků ve Slezsku (SV České republiky). Část 2 - Brachycera kromě Schizophora}

Př́ispěvek přináší nálezy 19 zajímavých druhů z čeledí Bombyliidae (1 druh), Mythicomyiidae (1 druh), Therevidae (2 druhy), Empididae (3 druhy), Hybotidae (1 druh), Dolichopodidae (8 druhů) a Syrphidae (3 druhy) zjištěné při výzkumu dipterofauny na glaciálních píscích v Českém Slezsku. Všechny to druhy jsou poprvé hlášeny z tohoto území, 4 z nich jsou nové pro faunu Moravy a 9 je nových pro území celé České Republiky. Podrobně je diskutována a hodnocena afinita všech prezentovaných druhů k písčitým biotopům. Dva druhy, viz Dialineura anilis (Linnaeus, 1761) (Therevidae) a Schistostoma truncatum (Loew, 1864) (Dolichopodidae) jsou klasifikovány jako psamobiontní, 6 druhů, viz Exhyalanthrax afer (Fabricius, 1794) (Bombyliidae), Cliorismia rustica (Panzer, 1804) (Therevidae), Cryptophlebs kerteszi Lichtwardt, 1898, Melanostolus melancholicus (Loew, 1869) (Dolichopodidae), Paragus constrictus Šimić, 1986 a Pelecocera tricincta Meigen, 1822 (Syrphidae) jako psamofilní, a 3 další druhy, viz Medetera annulitarsus von Roser, 1840, M. grunini Negrobov, 1966 a Sciapus basilicus Meuffels \& Grootaert, 1990 (všechny Dolichopodidae) jako pravděpodobně psamofilní. Druh Medetera grunini (Dolichopodidae) je poprvé hlášen z Evropy a jeho nálezy ze Slezska představují novou nejzápadnější hranici rozšíření. Nové nálezy druhů Rhamphomyia murina Collin, 1926 (Empididae) a Drapetis monsmargila Grootaert, Beuk \& Shamshev, 2020 (Hybotidae) jsou zase nejjižnější v Evropě.

Authors' addresses: Jindřich Roháček, Silesian Museum, Nádražní okruh 31, CZ-746 01 Opava,

Czech Republic.

E-mail: rohacek@szm.cz

Miroslav Barták, Czech University of Life Sciences, Faculty of Agrobiology, Food and Natural Resources, Department of Zoology and Fisheries, Kamýcká 129, CZ-165 00

Praha-Suchdol, Czech Republic.

E-mail: bartak@af.czu.cz

Alois Čelechovský, Department of Zoology and Laboratory of Ornithology, Faculty of Science, Palacký University, 17. listopadu 50, CZ-771 46 Olomouc, Czech Republic.

E-mail: celechov@prfnw.upol.cz

Patrick Grootaert, Royal Belgian Institute of Natural Sciences, Entomology, Vautier street 29, B-1000 Brussels, Belgium.

E-mail: pgrootaert@yahoo.co.uk

Liliana Kanavalová, Czech University of Life Sciences, Faculty of Agrobiology, Food and Natural Resources, Department of Zoology and Fisheries, Kamýcká 129, CZ-165 00 Praha-Suchdol, Czech Republic.

E-mail: kanavalova@af.czu.cz

Libor Mazánek, Jívová 231, CZ-783 16 Jívová, Czech Republic.

E-mail: syrphidae@centrum.cz

Marc Pollet, Research Institute for Nature and Forest (INBO), Herman Teirlinckgebouw, Havenlaan 88 bus 73, B-1000 Brussels, Belgium.

E-mail: mpollet.doli@gmail.com 